NBER WORKING PAPER SERIES

\title{
EXPECTATIONS, REFERENCE POINTS, AND COMPLIANCE WITH COVID-19 SOCIAL DISTANCING MEASURES
}

\author{
Guglielmo Briscese \\ Nicola Lacetera \\ Mario Macis \\ Mirco Tonin \\ Working Paper 26916 \\ http://www.nber.org/papers/w26916 \\ NATIONAL BUREAU OF ECONOMIC RESEARCH \\ 1050 Massachusetts Avenue \\ Cambridge, MA 02138 \\ March 2020
}

A version of this work limited to the first survey wave circulated as "Compliance with COVID-19 Social-Distancing Measures in Italy: The Role of Expectations and Duration" (NBER Working paper 26916). We gratefully acknowledge the financial support of the Sandra Rotman Centre for Health Sector Strategy at the University of Toronto and the Hopkins Business of Health Initiative. The study received approval by the Research Ethics Board of the University of Toronto (Protocol \#00039165) and by the Homewood Institutional Review Board of Johns Hopkins University (Protocol \#HIRB00010962). We thank Luigi Guiso and seminar participants at Bocconi University, OECD, the University of Pittsburgh, the University of Bologna, and the Society of Italian Economists (SIE) for useful comments. All authors contributed equally to this article. The views expressed herein are those of the authors and do not necessarily reflect the views of the National Bureau of Economic Research.

NBER working papers are circulated for discussion and comment purposes. They have not been peer-reviewed or been subject to the review by the NBER Board of Directors that accompanies official NBER publications.

(C) 2020 by Guglielmo Briscese, Nicola Lacetera, Mario Macis, and Mirco Tonin. All rights reserved. Short sections of text, not to exceed two paragraphs, may be quoted without explicit permission provided that full credit, including $\odot$ notice, is given to the source. 
Expectations, reference points, and compliance with COVID-19 social distancing measures Guglielmo Briscese, Nicola Lacetera, Mario Macis, and Mirco Tonin

NBER Working Paper No. 26916

March 2020, Revised in October 2020

JEL No. C42,D91,H12,H41,I12

\begin{tabular}{|c|c|}
\hline & TRACT \\
\hline $\begin{array}{l}\text { We surveyed representative samples of I } \\
\text { pandemic, to test whether and how intent } \\
\text { to the duration of their possible extensior } \\
\text { less likely to increase, their self-isolation } \\
\text { extension (i.e., if the extension is longer t } \\
\text { no impact. These results are consistent } \\
\text { expectations serving as a reference poin } \\
\text { authorities should carefully manage e } \\
\text { behavioral reactions to deviations from pr }\end{array}$ & $\begin{array}{l}\text { residents at three critical points in the } \\
\text { o comply with social-isolation restricti } \\
\text { ividuals reported being more likely to } \\
\text { rt if negatively surprised by a given } \\
\text { hat they expected), whereas positive s } \\
\text { reference-dependent preferences, with } \\
\text { loss aversion. Our findings indicate } \\
\text { ations about policy measures and } \\
\text { s announcements. }\end{array}$ \\
\hline Guglielmo Briscese & Mario Macis \\
\hline University of Chicago & Johns Hopkins University \\
\hline 5807 S Woodlawn Ave & Carey Business School \\
\hline Chicago, IL 60637 & 100 International Drive, Office 1333 \\
\hline gubri@uchicago.edu & $\begin{array}{l}\text { Baltimore, MD } 21202 \\
\text { and IZA }\end{array}$ \\
\hline Nicola Lacetera & and also NBER \\
\hline University of Toronto & mmacis@jhu.edu \\
\hline Institute for Management and Innovation & \\
\hline 3359 Mississauga Road, Room KN 235 & Mirco Tonin \\
\hline Mississauga, ON L5L 1C6 & mirco.tonin@unibz.it \\
\hline CANADA & \\
\hline and NBER & \\
\hline ola.lacetera@utoronto.ca & \\
\hline
\end{tabular}




\section{Introduction}

We study how government announcements and individuals' expectations about a policy's duration affect citizens' willingness to comply. We investigate this topic in the context of the COVID-19 pandemic, when compliance with lockdown measures was crucial to slow down the spread of the virus and alleviate the burden on the health systems (Baldwin and Weder di Mauro 2020). We conducted three cross-sectional surveys on representative samples of the Italian population at critical moments of the pandemic and found that the willingness to comply with the self-isolation measures is sensitive to how long citizens expect the measures to last in comparison with the end date announced by the government. Respondents expressed a lower willingness to comply with self-isolation measures if the possible extensions of these norms were longer than they expected. Moreover, individuals grew more impatient over time and reported a lower intention to comply after the government extended the duration of the lockdown.

Many public policies aim to influence citizens’ behavior. Policymakers can leverage on incentives and sanctions; however, strict enforcement is often costly, and voluntary compliance is crucial to achieve the desired behavior. Ensuring voluntary cooperation is particularly important when individuals do not fully internalize the negative effects that their behavior might have on others. The social distancing measures that many countries introduced to contrast the spread of COVID-19, ranging from limitations to gatherings to shelter-in-place orders, are a relevant example. In this context, one additional complication is that people might not even be aware of hurting others when violating socialdistancing rules, because many infected individuals are asymptomatic and unaware of being positive due to limited testing capabilities (especially so at the onset of the pandemic). Thus, voluntary compliance is critical (Watanabe and Yabu 2020), and so is the investigation of what factors motivate it (Maharaj and Kleczkowski 2012).

Some studies have documented that compliance with social distancing measures can depend on socio-economic constraints, e.g. whether citizens have access to flexible work arrangements (Papageorge et al. 2020), but also on behavioral factors, such as beliefs about the infectiousness of the virus (Akesson et al. 2020) and their sense of civic duty (Barrios et al. 2020; Durante et al. 2020). Our 
research provides evidence of another important behavioral factor: people's expectations of the duration of self-isolation measures.

In the spring of 2020, governments adopted different approaches to communicate the duration of the COVID-19 lockdown to the public; some implemented the measures "until deemed necessary", whereas others specified an end date. ${ }^{1}$ These choices identify a tension between different potential effects. On the one hand, limits to personal mobility and economic activity without setting an end date can increase the perceived severity of the crisis, thus improving compliance; at the same time, they might also increase anxiety or fatalism, thus potentially reducing the respect of the rules. ${ }^{2}$ On the other hand, a specific end date may be easier to communicate to the public, although it might convey the idea that the epidemic will be under control by that date. However, because of the uncertainty surrounding the pandemic's severity and its evolution, authorities could not rule out potential extensions to the announced end date of the restrictions. Lengthening the lockdown after having set clear expectations may reduce the public's acceptance, trust in the authority, and ultimately reduce compliance. ${ }^{3}$ These tensions witness the importance of understanding how citizens' willingness to comply with social distancing measures depends on the announced duration of the measures and their possible extensions.

The psychological mechanisms that we study, and their behavioral consequences, are akin to those identified in other contexts where reference points and expectations showed to influence decisions. Consistent with prospect theory (Kahneman and Tversky, 1979; Tversky and Kahneman, 1992),

\footnotetext{
${ }^{1}$ In the Hubei province of China, where the virus originated and first spread, authorities imposed a strict lockdown of the population without setting a defined end date (Yang and Kubota 2020; Hessler 2020). In Italy and other countries such as Canada, France, the United States, India and the United Kingdom, instead, the government enacted stay-at-home mandates specifying an end date for the measures. However, most countries extended the lockdowns beyond the end that that they had originally set. In Ontario (Canada), for example, two weeks after enacting a two-week public-school closing, the provincial government issued a further extension of the closure without defining an end date. The governments of France also considered an extension of the lockdown measures, with politicians and commentators debating whether the extension should be in place for an additional specified period of time, or indefinitely until necessary (France 24, 2020). Similarly, the British Prime Minister announced on March 23rd, referring to the just-introduced lockdown measures in the country that the government was going to revisit the end date after three weeks, and relax them only if the evidence showed that it was possible to do so (BBC News 2020; Davies and Diver 2020).

${ }^{2}$ Previous research found that quarantine measures have negative short and long-term psychological effects, including anxiety and post-traumatic stress, with even more severe effects for longer quarantines (Brooks et al. 2020). For the role of fatalism, see Akesson et al. (2020).

${ }^{3}$ Moser and Yared (2020) discuss additional tradeoffs that governments face when deciding between committing not to extend the lockdown measures beyond the date originally set or, instead, keeping open the option to extend them if the evolution of the epidemic makes it necessary.
} 
individuals have shown to value the outcomes of certain decisions based on an internal reference point. Abeler et al. (2011) show that reference points can be exogenously altered, and that high expectations can nudge workers to work longer hours and earn more money (see also Camerer et al., 1997 and Thakral and Tô, 2017 for similar results). Reference points have proved to influence efforts also in a variety of other settings, such as physical activity (Allen et al. 2017), buying decisions (Wenner, 2015; Köszegi and Rabin, 2006), ${ }^{4}$ and charitable giving (Exley and Terry, 2019).

In the context of our study, another implication of moving the deadline of the social distancing measures is the so-called "goal gradient" effect, according to which the farther a person is to a goal the less likely they exert effort to achieve it (Bonezzi et al. 2011; Heath et al. 1999). This effect is visible in several contexts, such as the dissatisfaction that consumers may have from experiencing a lower quality of a good or service than they expected, or that patients and airline passengers feel if wait times are longer than announced. These mis-confirmations may lead the individuals to not engage with a service or purchase a good again (e.g. see Craig et al., 2017). ${ }^{5}$ In the case of the COVID19 outbreak, moving the goalpost of when the social distancing measures will be lifted might have led to frustration among the public if they began to believe that the goal was unattainable (Huang et al. 2012; Louro et al. 2007).

Our study shows that citizens' willingness to comply with government policies is sensitive to expectations in a manner consistent with prospect theory, in a context where citizens' compliance has high stake consequences for public health. Because the evolution of the policy responses to COVID-19 in Italy resembles the subsequent experience of other countries, our results may extend beyond this specific case and have implications for the timing of policy announcements by other governments around the world. In this way, we offer insights on the importance of communication framing and expectation setting by governments interested in implementing behavioral change policies. This is particularly true for time-limited policies that inevitably set an expectation among the public about their

\footnotetext{
${ }^{4}$ For a review on reference price research, see Mazumdar et al. (2005)

${ }^{5}$ Insights for good and service providers vary; for example, foot-in-the-door techniques (asking initially for a small commitment, and escalate later) may facilitate initial adoption, but lead to a negative shock in the future. Door-in-the-face approaches, whereby the proposer starts by asking a strong commitment, may discourage adoption but, conditional on adopting, may lead to positive surprises and higher satisfaction and retention (Staw 1981; Kelly and Milkman, 2013).
} 
duration. Since acceptance and compliance by citizens are as difficult to achieve as important to the effectiveness of the policy, governments should pay attention to how they communicate interventions.

In the next section, we report the institutional background and the methodology of the study; in Section 3 we describe the data, and we discuss the results of the empirical analyses in Section 4 . We conclude, in section 5, with policy implications from our study and directions for future studies.

\section{Institutional background and survey}

In early 2020, Italy was the first Western country to implement a lockdown in response to the rapidly growing number of COVID-19 cases at the outset of the virus outbreak. The government first communicated the implementation of the lockdown as temporary and announced a specific end date that it later revised twice before gradually relaxing the measures (see Appendix A for a detailed account of COVID-19 events and policy responses in the country). Despite media coverage stressing the gravity of the virus, hefty fines and severe sanctions for lawbreakers, the Italian government initially struggled to ensure full compliance by the public.

To study how the duration of stay-at-home measures influenced compliance, we collaborated with a well-established survey firm to run three carefully timed surveys on representative samples of the Italian population. ${ }^{6}$ In Figure 1, we plot some indicators of the epidemiological developments, the timing of the main policy responses, and the timing of the three waves of our survey. The first wave ran on March 18-20, 2020, the second on April 8-10, and the third on April 22-24; the three waves reached nationally representative samples of 894, 891 and 912 individuals, respectively.

\footnotetext{
${ }^{6}$ SWG is one of the most established market research firms in Italy and a member of the European Society for Opinion and Marketing Research. The company manages a panel of over 60,000 individuals in the country. Respondents fill the surveys online or respond to questions via an online computer-assisted telephone interview (CATI) software. The firm began administering questions related to the COVID-19 epidemic in a weekly survey in late January 2020. We added a set of questions to three of SWG's surveys (questions in Italian and their English translation are in Appendix B).
} 
FIGURE 1: Timeline of COVID-19 epidemic and policy responses in Italy

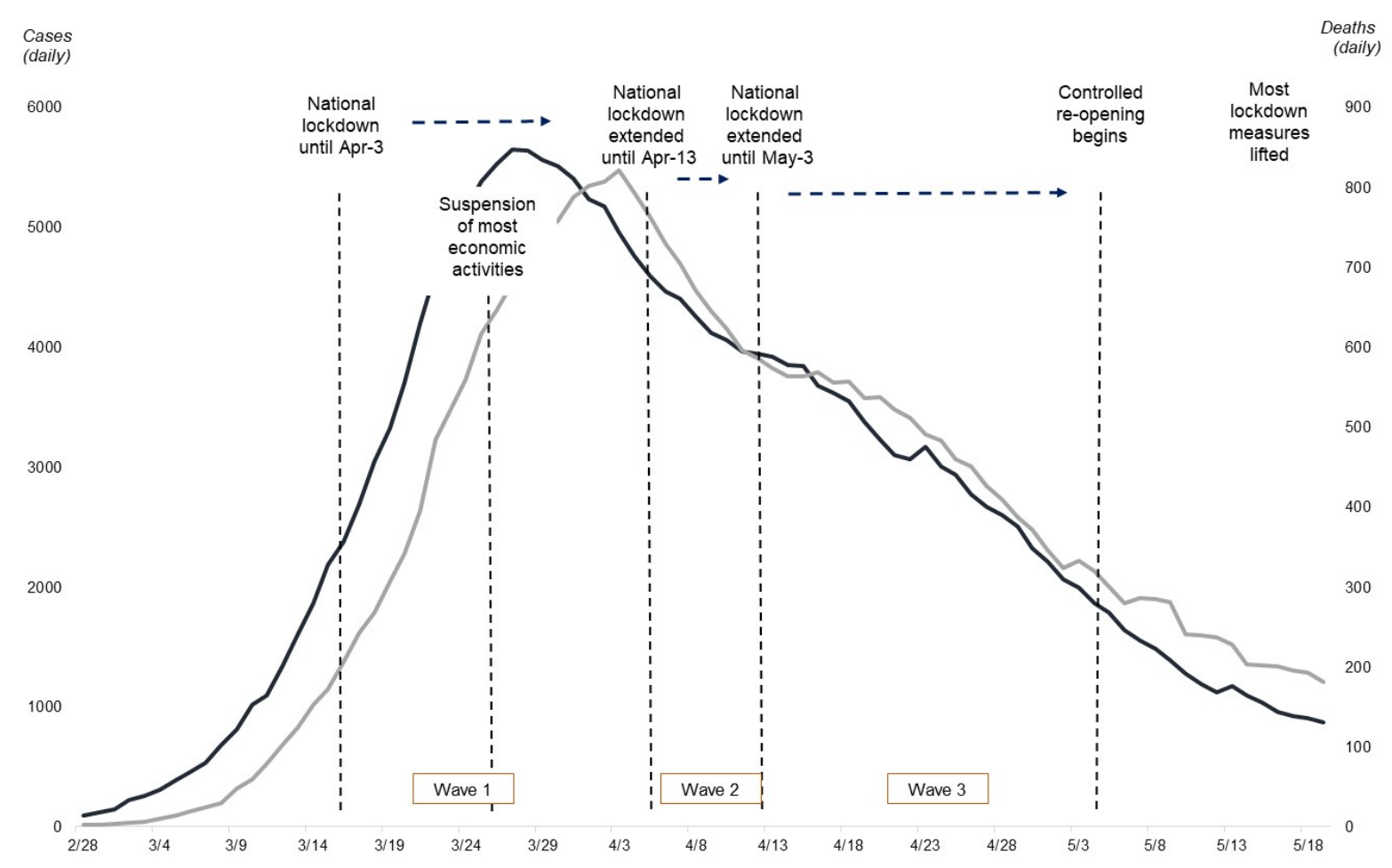

Notes: Source: authors' calculations based on European Centre for Disease Prevention and Control data. Last update May 19, 2020.

Each survey wave had four main parts. In the first part, respondents answered questions about what actions they were adopting to reduce the likelihood of contagion.

Next, we measured respondents' awareness of the official end date of the stay-at-home measures by asking them to report it. Third, after showing all respondents the officially announced end date to fix for heterogeneous levels of awareness (April 3 in wave 1, April 13 in wave 2, and May 3 in wave 3), we recorded the respondents' subjective expectations on possible extensions of the measures. In this question, there were four statements and we asked participants to choose the one they believed would be most likely to occur. The options were as follows: (a) "the measures will end on the date indicated by the Government"; (b) "the measures will be extended by a few weeks"; (c) "the measures will be extended by a few months"; and (d) "the measures will be extended indefinitely, until deemed necessary”. Finally, we asked respondents to consider a set of scenarios with different extensions of the stay-at-home measures, and to indicate their intentions to comply with the restrictions under each scenario. There were three cases for them to consider, each with a different duration of the extension: 
"by a few weeks”, "by a few months”, “indefinitely, until deemed necessary”. In each scenario, participants would select one of five options: "I would significantly increase my isolation”, "I would somewhat increase my isolation”, "I would continue in my current behavior", "I would somewhat reduce my isolation", "I might decide not to comply with the rules". We presented the scenarios in random sequence to avoid ordering effects. This design allows us to determine whether the duration of the extension affects intentions to comply with stay-at-home measures. Further, we can assess whether any given extension represented a surprise (positive if the extension is shorter than what the respondent expected, negative otherwise) or was close to individuals' expectations. The survey also included a module with questions about the respondents' socio-demographic characteristics.

\section{Data and descriptive statistics}

\section{Characteristics of the sample}

Table 1 reports the summary statistics of the socio-demographic characteristics of the sample, both overall and for each survey wave. $39.7 \%$ of respondents live in one of the five regions ${ }^{7}$ where the disease initially spread on a larger scale (i.e., the "Red Zone" - see Appendix A). 17.2\% reside in Lombardia, the region that experienced the largest number of COVID-19 cases and deaths. 32.8\% of participants are older than 60 , and as such, are in the sub-population at highest risk of severe effects from COVID-19. ${ }^{8}$ We also report summary statistics on the number of social-isolation behaviors that respondents reported having adopted. On average, respondents adopted 4.3 of the 6 recommended behaviors listed in the survey, and $46 \%$ of the sample reported adopting all six recommended behaviors. ${ }^{9}$ Table $\mathrm{C} 1$ in Appendix C shows these statistics for various relevant sub-groups.

\footnotetext{
${ }^{7}$ The five regions were Lombardia, Veneto, Marche, Piemonte, Emilia-Romagna.

${ }^{8}$ See: https://www.cdc.gov/coronavirus/2019-ncov/need-extra-precautions/older-adults.html.

${ }^{9}$ The six recommended behaviors listed in the survey were: "I try to keep a safe distance from people", "I do not go to crowded places", "I go to supermarkets as seldom as possible", "I no longer meet with friends", "I no longer meet with relatives who do not live with me", and "I do not leave home except in an emergency". Due to a coding error, in the second wave the survey firm coded this question as single-response instead of multiple-response. We have thus discarded the question from wave 2. See Appendix Tables C2 and C3 for details.
} 


\section{Awareness of end date of stay-at-home provisions}

To achieve widespread compliance, awareness of a policy’s provisions is crucial. A large majority of respondents reported accurately the date that the Italian government had announced as the deadline for the stay-at-home measures as of the date of the survey (i.e., April 3, April 13 and May 3 for the first, second and third wave, respectively). The share of respondents who reported the correct date was $77.2 \%$ overall (73.5\% in wave $1,64.7 \%$ in wave 2 , and $93.4 \%$ in wave 3 ; see Table C4 in the Appendix). ${ }^{10}$ These findings indicate that in spite of a large share of the population being knowledgeable about the relevant deadlines, between $25 \%-30 \%$ of the population was either confused or not well informed about the timeline of the measures.

TABLE 1: Characteristics of the survey respondents

\begin{tabular}{|c|c|c|c|c|}
\hline & Full sample & Wave 1 & Wave 2 & Wave 3 \\
\hline Women & $51.9 \%$ & $51.9 \%$ & $51.9 \%$ & $51.9 \%$ \\
\hline Age & 50.7 & 50.7 & 51.1 & 50.3 \\
\hline Completed high school & $65.9 \%$ & $66.2 \%$ & $66.4 \%$ & $64.9 \%$ \\
\hline College degree & $19.5 \%$ & $19.2 \%$ & $20.1 \%$ & $19.2 \%$ \\
\hline Lives alone & $14.1 \%$ & $13.2 \%$ & $14.4 \%$ & $14.9 \%$ \\
\hline Lives with parents & $12.4 \%$ & $11.7 \%$ & $11.7 \%$ & $13.7 \%$ \\
\hline Married & $62.6 \%$ & $63.3 \%$ & $64.2 \%$ & $60.4 \%$ \\
\hline Has children & $63.6 \%$ & $64.1 \%$ & $63.1 \%$ & $63.5 \%$ \\
\hline Employed & $51.7 \%$ & $53.1 \%$ & $51.9 \%$ & $49.9 \%$ \\
\hline Economically comfortable & $45.0 \%$ & $44.6 \%$ & $45.7 \%$ & $44.6 \%$ \\
\hline Facing economic difficulties & $55.0 \%$ & $55.4 \%$ & $54.3 \%$ & $55.4 \%$ \\
\hline Compliance with social-isolation measures & 4.3 & 4.5 & NA & 4.1 \\
\hline Adopting all social-isolation measures & $46.1 \%$ & $49.9 \%$ & NA & $42.2 \%$ \\
\hline Age $60+$ & $32.8 \%$ & $32.3 \%$ & $33.7 \%$ & $32.5 \%$ \\
\hline Lives in Red Zone & $39.7 \%$ & $41.7 \%$ & $37.3 \%$ & $39.8 \%$ \\
\hline Lives in Lombardia & $17.2 \%$ & $17.6 \%$ & $17.8 \%$ & $16.3 \%$ \\
\hline $\mathrm{N}$ & 2697 & 894 & 891 & 912 \\
\hline
\end{tabular}

Notes: The table reports the average age of participants as well as percentages of participants with certain characteristics. Red Zone refers to the following regions: Emilia Romagna, Lombardia, Marche, Piemonte, Veneto. The variable "economically comfortable" indicates respondents who reported that their household income allows them to live "comfortably" or "without concerns". The variable "Facing economic difficulties" identifies respondents who reported that they "are having economic difficulties", "make to the end of the month with much struggling", or "are poor and their income does not allow them to make it to the end of the month". "Compliance with social-isolation measures" is the number of social-isolation measures respondents report having adopted, and "adopting all social-isolation measures" is the percentage of respondents who reported adopting all recommended measures (see Appendix Tables C2 and C3 for details). We used sampling weights (provided by SWG) to compute these statistics.

10 The proportions are similar among red-zone residents and those living in the rest of the country (77.3\% vs. $77.2 \%)$ and among respondents younger than 60 and older than 60 (76.9\% vs. 77.6\%). 
Respondents' expectations about possible extensions of stay-at-home measures

As shown in Figure 2, the distribution of expectations about the duration of possible extensions of the stay-at-home measures was different across the three waves. In the first wave (conducted in the early, ascending, stage of the epidemic), only $2.8 \%$ of respondents believed that the lockdown would end on the official date (April 3). 42.7\% expected the government to extend the provisions by a few weeks, 20.4\% by a few months, and $34.1 \%$ for an indefinite time. In the second wave (during the "plateau" portion of the epidemiological curve in the country), again only a few responded expected the measures to end at the (new) official date (April 13), but many more believed the extension to last only a few weeks compared to wave 1 (70.9\%), and fewer expected longer extensions. In the third wave, we observe an increase in this trend with nearly $40 \%$ of respondents expecting that the lockdown would actually end on the (new) date (May 3), almost half believing it would last only a few more weeks, and a small minority expecting extensions by months or an undetermined time. ${ }^{11}$ The shift in expectations, with an increasing share of respondents expecting an earlier end of the social distancing rules, followed at least in part the evolution of the epidemic and the actual policy. Considerable heterogeneity remained, however, within each wave about how long the measures would remain in place.

\footnotetext{
11 These proportions are similar among residents of red-zone and non-red zone regions, and among respondents younger than 60 and those older than 60 (see Table C5 in the Appendix)
} 
FIGURE 2: Expected end date of self-isolation measures

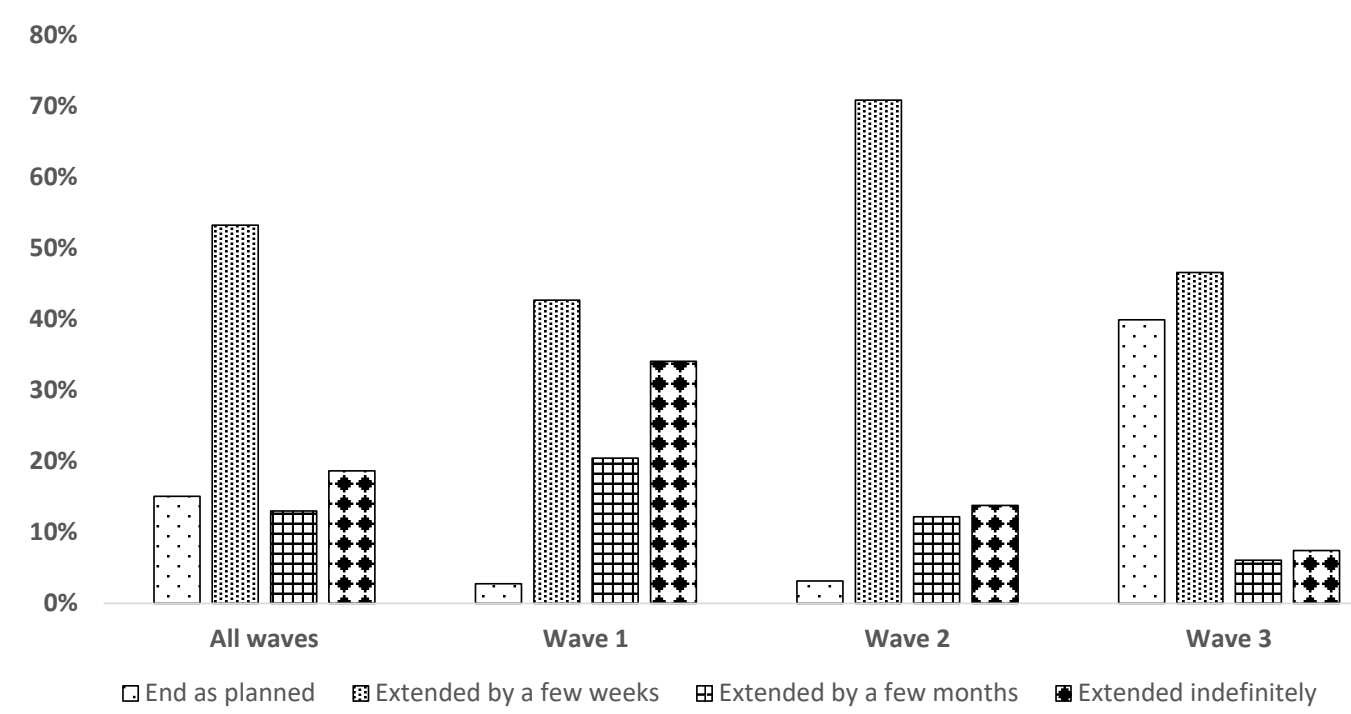

Notes: The graph reports the sampling-weighted proportions of respondents who reported their expectation that the self-isolation measures would end as planned, or be extended by a few weeks, a few months, or until necessary. The design-based $\mathrm{F}$ statistic for equality of distribution of expectations between the three waves is $73.1(\mathrm{p}<0.001)$.

\section{Analyses}

Figure 2 shows that there is a discrepancy between the duration of the self-isolation measures expected by citizens and that announced by the government. The analyses we present in this section offer insights as to how individuals respond to government communication, and the extent to which they rely on their own beliefs. Analyzing expectations as reference points is also informative as to the nature of preferences; in particular, we can test whether positive or negative "surprises" (i.e., the duration of selfisolation restrictions is shorter or longer than expected, respectively) have a similar or asymmetric effect on intentions to comply. We first report some descriptive graphical evidence and then turn to regression analyses.

\section{Announced lockdown extensions and self-isolation intentions}

In Figure 3 we report the distribution the respondents' intentions to comply with stay-at-home restrictions under the three scenarios of potential extensions to the date announced by the government at a given time: “a few weeks", “a few months”, or "indefinitely”. Because extreme compliance intensions were infrequent, we grouped intentions to comply categories into three: “maintain”, “reduce” 
(combining "would reduce self-isolation” and "would consider no longer respecting the rules”), and "increase" ("increase somewhat" and "increase greatly" self-isolation efforts) ${ }^{12}$. Most respondents (between 63\% and 70\%) in all scenarios indicated that they intended to "maintain" their current selfisolation efforts, with a decline in case of longer extensions. The proportion of respondents who intended to increase self-isolation is similar across the three scenarios (between $17.2 \%$ and $17.7 \%$ ). Conversely, the share of respondents who would reduce it increases with the length of the expected extensions, going from $12.4 \%$ in the scenario where the lockdown is extended by a few weeks to $19.5 \%$ in the case of indefinite extension. There are also differences across waves, with a drop in the proportion of respondents who intend to increase their compliance and a rise in those decreasing it in more recent waves (see Appendix for details). Intentions to comply are thus sensitive to the hypothesized duration of lockdown extensions. This could be due to the cost of isolation increasing with its duration. As a longer lockdown is plausibly connected to more severe epidemiological environments, also its benefits could increase with duration, but not necessarily as steeply as the cost.

FIGURE 3: Self-isolation intentions, by hypothesized duration of lockdown extension

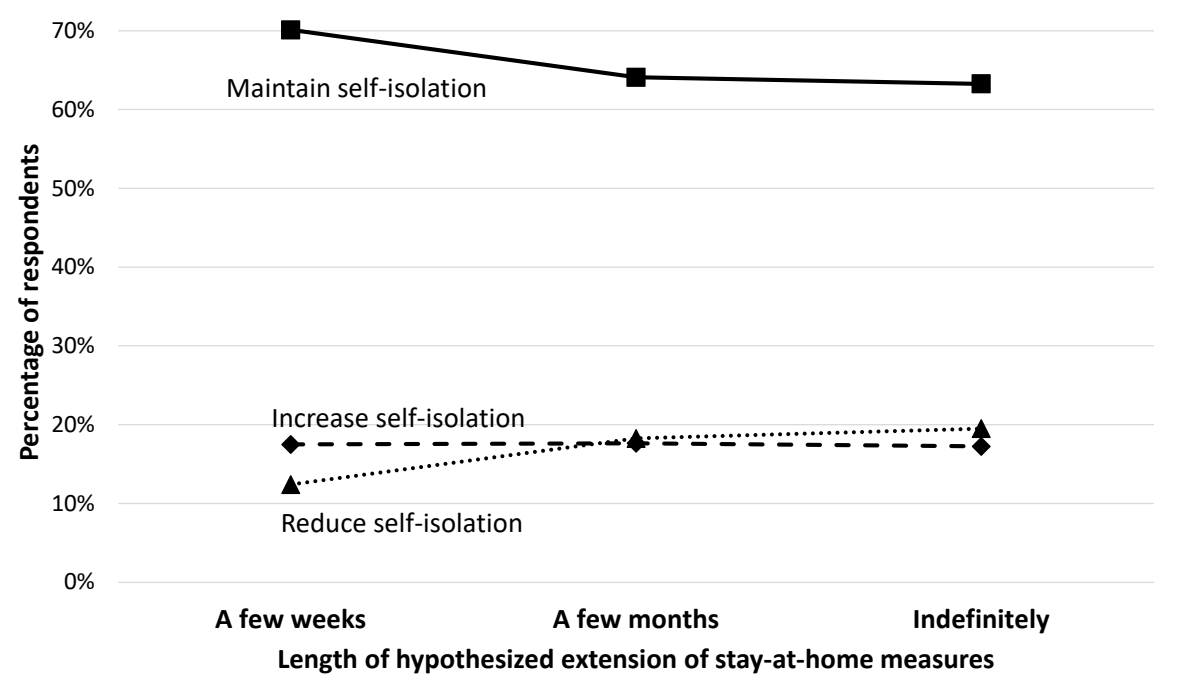

Notes: The graph reports the sampling-weighted proportion of respondents who stated their intention to increase, maintain, or reduce their compliance with self-isolation measures, by hypothesized extension scenarios. "Increase self-isolation" corresponds to the intention to either "increase substantially" or "increase somewhat" self-isolation; "Reduce self-isolation" includes the options "reduce somewhat" or "consider not complying with restrictions"; "Maintain self-isolation" indicates intention to "continue with current self-isolation behavior". The design-based F statistic for the test of equality of distribution in the five (mis)match cases is $21.9(\mathrm{p}<0.001)$.

${ }^{12}$ We report the full distributions in Appendix Figure C1. 


\section{Expectation on extensions and self-isolation intentions}

To investigate the extent to which intentions to comply with the lockdown depended on individual expectations about how long the measures would be in place, we defined a measure of match (or mismatch) between expectations and extension scenarios (see Table 2). A "match" occurs when the extension scenario coincides with the respondents' expectations. Mismatch cases can be positive or negative: "shorter" and "much shorter" indicate instances where the scenario hypothesizes that the measures will end sooner than the respondent expects, whereas "longer" and "much longer" denote cases in which the hypothesized extension dates end later than a respondent's expectation. ${ }^{13}$

TABLE 2: (Mis)match between expectations and hypothesized length of extension of stay-at-home measures

\begin{tabular}{|c|c|c|c|c|}
\hline & & \multicolumn{3}{|c|}{ Scenario } \\
\hline & & $\begin{array}{l}\text { Extended by a } \\
\text { few weeks }\end{array}$ & $\begin{array}{l}\text { Extended by a } \\
\text { few months }\end{array}$ & $\begin{array}{c}\text { Extended } \\
\text { indefinitely } \\
\text { (until necessary) }\end{array}$ \\
\hline \multirow{4}{*}{ 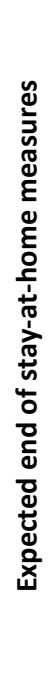 } & $\begin{array}{c}\text { End on } \\
\text { announced date }\end{array}$ & longer & $\begin{array}{l}\text { much } \\
\text { longer }\end{array}$ & $\begin{array}{l}\text { much } \\
\text { longer }\end{array}$ \\
\hline & $\begin{array}{l}\text { Extended by a } \\
\text { few weeks }\end{array}$ & match & longer & $\begin{array}{l}\text { much } \\
\text { longer }\end{array}$ \\
\hline & $\begin{array}{l}\text { Extended by a } \\
\text { few months }\end{array}$ & shorter & match & longer \\
\hline & $\begin{array}{c}\text { Extended } \\
\text { indefinitely } \\
\text { (until necessary) }\end{array}$ & $\begin{array}{l}\text { much } \\
\text { shorter }\end{array}$ & shorter & match \\
\hline
\end{tabular}

Notes: The rows of this table report the lockdown extension scenarios presented to the respondents; the columns refer to the respondents' expectations about the duration of the lockdown. We indicate as a "match" the cases in which the expectations corresponded to the hypothesized extensions. "Shorter" and "much shorter" correspond to cases where the hypothesized duration of the measures is less than the expected duration; "longer" and "much longer" indicate that the scenario hypothesizes the measures to end later than expected.

\footnotetext{
${ }^{13}$ Potentially, we could create a further category for the combination "end on announced date"-"extended indefinitely", but we consider the shock of an indefinite extension not too different between those expecting an immediate end and those expecting a few weeks extension and, therefore, keep them in the same category.
} 
Figure 4 shows the distribution of self-isolation intentions by the (mis)match between expectations and hypothesized extension scenario. The sampling-weighted averages show that the proportion of respondents who report a willingness to increase compliance with self-isolation measures decreases as the hypothesized extension of the measures gets longer than the respondents expected. Conversely, the more negative the surprise between scenario and expectations, the higher is the proportion of individuals expressing the intention to reduce their level of compliance. For extreme mismatches (where the scenario is much longer than expectations), the share of respondents who indicate they would reduce compliance is higher than the share of those who would increase it. We find similar patterns in each wave (see Figure C2 in Appendix C). We also observe an asymmetry between positive surprises, which are not associated with changes in compliance intentions, and negative ones, for which we find a reduction in compliance intentions. This is consistent with reference-dependent preferences, with expectations acting as reference points, and with individuals placing more weight on negative than positive news.

FIGURE 4: Self-isolation intentions, by (mis)match between expectations and extension scenarios

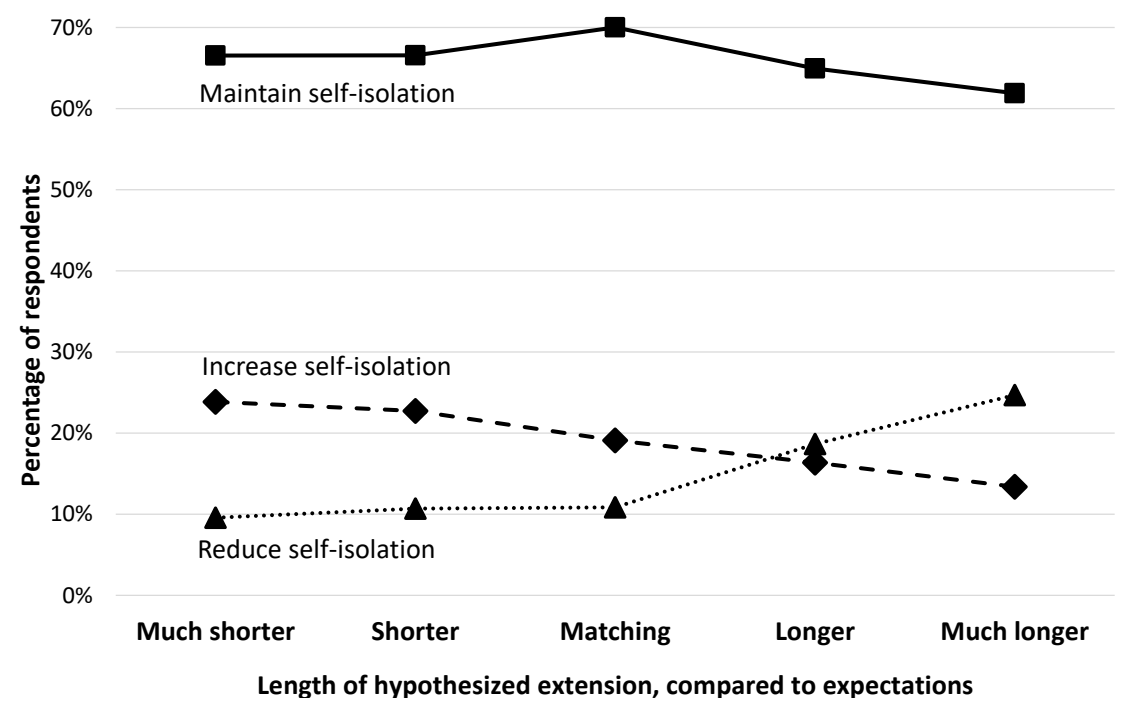

Notes: The graph reports the sampling-weighted proportion of respondents who stated their intention to increase, maintain, or reduce their compliance with self-isolation measures, by (mis)match between the hypothesized extension scenarios and their expectation about this extension. "Increase selfisolation" corresponds to the intention to either "increase substantially" or "increase somewhat" selfisolation; "Reduce self-isolation" includes the options "reduce somewhat" or "consider not complying with restrictions"; "Maintain self-isolation" indicates intention to "continue with current self-isolation behavior". The design-based F statistic for the test of equality of distribution in the five (mis)match cases is $18.29(\mathrm{p}<0.0001)$. 


\section{Regression analyses}

We investigate the statistical significance of these differences, and their robustness to controls, with multinomial regressions analyses. The outcome variable is the choice between increasing, maintaining (the default option) and reducing compliance. The covariates on which we focus are the different extension scenarios, the expectations about extensions that the respondent reported, and the type of mismatch between scenarios and expectations. Additional covariates include indicators for each wave, and the set of socio-demographic features reported in Table 1 . Table 3 reports the parameter estimates in relative-risk-ratio transformations. For each specification, the first column displays the estimated coefficients for the option to increase compliance, and the second the estimates for the option to reduce compliance.

The estimated coefficients from specification (1) indicate that respondents, on average, were significantly more likely to express the intention to reduce their compliance when presented with a scenario that implied an extension longer than a few weeks. They were also less likely to report a willingness to increase (and more likely to decrease) compliance in wave 3. In specification (2) we included indicators of the respondents' expectations, setting “the lockdown will end as planned" as the omitted category. Respondents who expected that the government would extend the duration of the lockdown were less likely to report the intention to reduce compliance compared to those who expected the lockdown to end on the announced date (without any large or statistically significant differences across groups who expected different extensions). In specification (3) we add among the covariates the deviations from the extension scenarios, with "extension matching expectations" as the omitted category. The results confirm the descriptive evidence from Figure 4. Respondents who experienced negative surprises were significantly less likely to report the intention to increase compliance, and (especially) more likely to report the intention to reduce it, compared with the "extension matching expectations" case. Positive surprises imply reactions in the opposite direction, although these effects are weaker and, in most cases, not statistically significant. Wald tests for differences between the estimated coefficients on the positive and negative surprise indicators provide further evidence of the 
significance of the asymmetric effect of deviations of extension scenarios from expectations. ${ }^{14,15}$ Thus, the most significant reaction (statistically and in size) to the discrepancy between extension scenarios and expectations is the intention to reduce compliance when the hypothesized extension is longer than expected, while the reaction to shorter than expected extensions is negligible. These findings are consistent with expectations serving as reference points, and loss aversion triggering a stronger reaction in the loss domain.

Because expectations about the duration of the lockdown measures vary, we can further investigate whether all types of expectations are equally relevant reference points. Some respondents believed that the isolation restrictions would end at the officially announced dates. This was more frequent in the third wave. Because the official date was plausibly salient, a question is whether it was also a stronger reference point. This question is also relevant for policy, if announcing a specific end date generates a salient reference that is consequential for compliance intentions. Here we focus on the negative surprise effect because it is stronger and more consistent. In specification (4), we report estimates from regressions where the covariates include interaction terms between the indicators for the hypothesized extension being longer than the expectations, and the different expectations. Given the increased detail of the analysis, we grouped the expectation-mismatch indicators for "shorter" and "much shorter", and for "longer" and "much longer" into only two categories ("shorter" and "longer", respectively). The estimates show that the negative reactions to expectation mismatches are particularly strong for those who expected an end of the lockdown at the announced date (who are more likely to reduce compliance), as well as for those who expected an extension by a few weeks (who are less likely to increase compliance). The non-significant effects for those expecting the lockdown to be extended by

\footnotetext{
${ }^{14}$ In Appendix Table C6, we show that the results are robust to controlling for respondents' baseline levels of compliance, both using a binary indicator for whether the respondents reported complying with all six listed social-isolation behaviors (as seen in Table 1, this splits the sample approximately in half), and using the number (count) of social-isolation measures respondents report having adopted.

${ }^{15}$ In Appendix Table C7, we present results from specifications that include indicators for scenarios and expectations both directly and in deviations from the scenarios. Although there is some variation in deviations for each level of expectations, this variation is many cases limited to one or two categories, which makes the interpretation of the coefficients on the expectations-scenario deviations indicators problematic. To mitigate the concern, in Table C6 we present results after aggregating "shorter" and "much shorter" into one category ("shorter") and "longer" and "much longer" into one category ("longer"). Although the estimated coefficients are smaller in magnitude, our main result that negative surprises lead to reduced compliance is robust to this alternative specification.
} 
a few months suggest that the difference between an extension by a few months and an indefinite one may not be very strong.

TABLE 3: Self-isolation intentions: Multinomial Logit estimates

\begin{tabular}{|c|c|c|c|c|c|c|c|c|c|}
\hline \multirow{2}{*}{\multicolumn{2}{|c|}{ Option: }} & \multicolumn{2}{|c|}{ (1) } & \multicolumn{2}{|c|}{$(2)$} & \multicolumn{2}{|c|}{ (3) } & \multicolumn{2}{|c|}{ (4) } \\
\hline & & $\begin{array}{l}\text { Increase } \\
\text { compliance }\end{array}$ & $\begin{array}{l}\text { Reduce } \\
\text { compliance }\end{array}$ & $\begin{array}{l}\text { Increase } \\
\text { compliance }\end{array}$ & $\begin{array}{l}\text { Reduce } \\
\text { compliance }\end{array}$ & $\begin{array}{l}\text { Increase } \\
\text { compliance }\end{array}$ & $\begin{array}{l}\text { Reduce } \\
\text { compliance }\end{array}$ & $\begin{array}{l}\text { Increase } \\
\text { compliance }\end{array}$ & $\begin{array}{l}\text { Reduce } \\
\text { compliance }\end{array}$ \\
\hline \multirow[t]{3}{*}{ Scenario } & A few months & $\begin{array}{c}1.105^{*} \\
(0.0579)\end{array}$ & $\begin{array}{c}1.638^{* * *} \\
(0.105)\end{array}$ & $\begin{array}{l}1.106^{*} \\
(0.0582)\end{array}$ & $\begin{array}{c}1.651^{* * *} \\
(0.107)\end{array}$ & $\begin{array}{c}1.296 * * * \\
(0.129)\end{array}$ & $\begin{array}{c}1.234 \\
(0.161)\end{array}$ & $\begin{array}{c}1.340^{* * *} \\
(0.111)\end{array}$ & $\begin{array}{c}1.489 * * * \\
(0.138)\end{array}$ \\
\hline & Until Needed & $\begin{array}{c}1.092 \\
(0.0684)\end{array}$ & $\begin{array}{c}1.780 * * * \\
(0.128)\end{array}$ & $\begin{array}{c}1.093 \\
(0.0687)\end{array}$ & $\begin{array}{c}1.798^{* * *} \\
(0.131)\end{array}$ & $\begin{array}{c}1.508 * * \\
(0.243)\end{array}$ & $\begin{array}{c}1.095 \\
(0.225)\end{array}$ & $\begin{array}{c}1.371 * * * \\
(0.162)\end{array}$ & $\begin{array}{c}1.606 * * * \\
(0.187)\end{array}$ \\
\hline & A few weeks & & & $\begin{array}{c}0.759 \\
(0.188)\end{array}$ & $\begin{array}{l}0.441^{* * *} \\
(0.0850)\end{array}$ & & & & \\
\hline \multirow[t]{2}{*}{ Expectations } & Until needed & & & $\begin{array}{c}1.081 \\
(0.305) \\
1.150 \\
(0.316)\end{array}$ & $\begin{array}{c}0.425^{* * *} \\
(0.114) \\
0.387^{* * *} \\
(0.113)\end{array}$ & & & & \\
\hline & Much shorter & & & & & $\begin{array}{l}1.378^{*} \\
(0.266)\end{array}$ & $\begin{array}{c}1.026 \\
(0.285)\end{array}$ & & \\
\hline \multirow{3}{*}{$\begin{array}{r}\text { Length of } \\
\text { hypothesized } \\
\text { extension, relative to } \\
\text { expectations: }\end{array}$} & Shorter & & & & & $\begin{array}{c}1.106 \\
(0.131)\end{array}$ & $\begin{array}{c}0.993 \\
(0.163)\end{array}$ & & \\
\hline & Longer & & & & & $\begin{array}{c}0.865 \\
(0.0886)\end{array}$ & $\begin{array}{c}1.535^{* * *} \\
(0.212)\end{array}$ & & \\
\hline & Much longer & & & & & $\begin{array}{c}0.686 * * \\
(0.121)\end{array}$ & $\begin{array}{c}2.032 * * * \\
(0.454)\end{array}$ & & \\
\hline $\begin{array}{r}\text { Length of } \\
\text { hypothesized }\end{array}$ & Shorter & & & & & & & $\begin{array}{c}1.150 \\
(0.141)\end{array}$ & $\begin{array}{c}1.038 \\
(0.183)\end{array}$ \\
\hline \multicolumn{10}{|c|}{ extension relative to } \\
\hline $\begin{array}{r}\text { expectations } * L \\
\text { expectations } \epsilon\end{array}$ & $\begin{array}{l}\text { Longer * Expect lockdown to } \\
\text { end on announced date }\end{array}$ & & & & & & & $\begin{array}{c}1.019 \\
(0.249)\end{array}$ & $\begin{array}{c}2.664 * * * \\
(0.557)\end{array}$ \\
\hline b & $\begin{array}{l}\text { Longer * Expect lockdown to } \\
\text { be extended by a few weeks } \\
\text { Longer* Expect lockdown to } \\
\text { be extended by a few months }\end{array}$ & & & & & & & $\begin{array}{c}0.709 * * * \\
(0.0882) \\
1.002 \\
(0.195)\end{array}$ & $\begin{array}{c}1.258 \\
(0.177) \\
1.165 \\
(0.277)\end{array}$ \\
\hline \multirow[t]{2}{*}{ Wave: } & Wave 2 & $\begin{array}{l}0.759^{*} \\
(0.119)\end{array}$ & $\begin{array}{c}0.910 \\
(0.159)\end{array}$ & $\begin{array}{c}0.853 \\
(0.137)\end{array}$ & $\begin{array}{c}0.882 \\
(0.172)\end{array}$ & $\begin{array}{c}0.824 \\
(0.130)\end{array}$ & $\begin{array}{c}0.826 \\
(0.160)\end{array}$ & $\begin{array}{c}0.831 \\
(0.132)\end{array}$ & $\begin{array}{c}0.872 \\
(0.166)\end{array}$ \\
\hline & Wave 3 & $\begin{array}{c}0.572 * * * \\
(0.0937)\end{array}$ & $\begin{array}{c}2.299 * * * \\
(0.350)\end{array}$ & $\begin{array}{c}0.616 * * \\
(0.116)\end{array}$ & $\begin{array}{c}1.592 * * \\
(0.306)\end{array}$ & $\begin{array}{c}0.665^{* *} \\
(0.116)\end{array}$ & $\begin{array}{c}1.856 * * * \\
(0.330)\end{array}$ & $\begin{array}{c}0.599 * * * \\
(0.112)\end{array}$ & $\begin{array}{c}1.574 * * \\
(0.298)\end{array}$ \\
\hline \multirow{4}{*}{$\begin{array}{r}\text { Adjusted Wald test } \\
\text { of differences } \\
\text { (F-stat) }\end{array}$} & Longer - Shorter & & & & & 2.21 & $3.97 * *$ & & \\
\hline & Observations & \multicolumn{2}{|c|}{7,917} & \multicolumn{2}{|c|}{7,917} & \multicolumn{2}{|c|}{7,917} & \multicolumn{2}{|c|}{7,917} \\
\hline & F-statistic & \multicolumn{2}{|c|}{6.7} & \multicolumn{2}{|c|}{7.1} & \multicolumn{2}{|c|}{6.2} & \multicolumn{2}{|c|}{6.7} \\
\hline & N. respondents & \multicolumn{2}{|c|}{2,639} & \multicolumn{2}{|c|}{2,639} & \multicolumn{2}{|c|}{2,639} & \multicolumn{2}{|c|}{2,639} \\
\hline
\end{tabular}

Notes: The baseline option is "maintain current behavior", the omitted scenario is "a few weeks", and the omitted wave is Wave 1. We report the estimates as relative risk ratios. Each respondent selected one option from each of three questions, therefore there are up to three observations per individual in the regression sample. All regressions include, among the covariates, gender, age, education, whether the respondent lives alone or with her/his parents, marital status, whether the respondent has children, whether s/he is currently employed, whether the respondents' household is currently facing economic difficulties, and whether they live in one of the "Red Zone" regions. The regressions include sampling weights. Linearized standard errors are in parenthesis. ${ }^{* * *} \mathrm{p}<0.01,{ }^{* *} \mathrm{p}<0.05$, ${ }^{*} \mathrm{p}<0.1$ 


\section{Discussion}

Announcements belong in the policymakers' toolkit to affect citizens' behavioral response to policies. In the context of the COVID-19 pandemic, governments heavily relied on citizens' willingness to comply with social-distancing measures to reduce the spread of the virus. Achieving full compliance via strong formal enforcement (e.g. fines, geo-tracking) is not only controversial in democratic countries but also costly to implement. Hence, persuading the public to self-isolate is a critical mechanism.

To maximize the effectiveness of temporary isolation efforts, authorities must manage public expectations about when such measures will be relaxed or lifted. Our findings show that expectations about the duration of social isolation measures influence the public's intention to comply. Importantly, people's willingness to comply in case of an extension depends on how the length of this extension compares with their own expectations. Negative surprises (i.e., lockdown measures will be in effect for a longer time than expected) are associated with a lower willingness to increase compliance. These results are consistent with and contribute to a growing literature that explores the role of expectations as reference points, and the asymmetric effect of positive and negative deviations of realized scenarios from expectations.

One caveat of our study is that we measure intentions to comply with social-distancing restrictions, rather than actual behavioral change due to extensions of the measures. As such, social desirability bias could be a concern, as people may be inclined to understate the extent into which they are considering reducing their effort, attenuating our estimates of a negative surprises. However, respondents' identities were unknown to the researchers, and the fact that even in the middle of the epidemic more than half of participants admitted not complying with some of the social distancing measures suggests that social desirability may not be a crucial concern in this context, as recent evidence shows (Jensen, 2020).

Because the evolution of policy responses to COVID-19 in Italy resembles that of other countries, our results may extend beyond the national boundaries and have implications for policy announcements by other governments around the world. More broadly, our findings provide insights to public authorities on how to manage people's expectations in public health emergencies that require prolonged or intermittent lockdown measures. 


\section{References}

Abeler, J., Falk, A., Goette, L., \& Huffman, D. (2011). "Reference points and effort provision”. American Economic Review, 101(2), 470-92.

Akesson, J., Ashworth-Hayes, S., Hahn, R., Metcalfe, R.D. and Rasooly, I. (2020). "Fatalism, Beliefs, and Behaviors During the COVID-19 Pandemic”, (No. w27245). National Bureau of Economic Research.

Allen, E. J., Dechow, P. M., Pope, D. G., \& Wu, G. (2017). "Reference-dependent preferences: Evidence from marathon runners”. Management Science, 63(6), 1657-1672.

Baldwin, R and B Weder di Mauro (2020), Mitigating the COVID Economic Crisis: Act Fast and Do Whatever It Takes, VoxEU.org eBook, CEPR Press.

Barrios, J. M., Benmelech, E., Hochberg, Y. V., Sapienza, P., \& Zingales, L. (2020). “Civic capital and social distancing during the covid-19 pandemic" (No. w27320). National Bureau of Economic Research.

BBC News (2020): Coronavirus: Europe looking to extend virus lockdowns, BBC News, March 19, 2020. https://www.bbc.com/news/world-europe-51959243

Brooks, S.K., Webster, R.K., Smith, L.E., Woodland, L., Wessely, S., Greenberg, N. and Rubin, G.J. (2020). The psychological impact of quarantine and how to reduce it: rapid review of the evidence. The Lancet.

Bonezzi, A., Brendl, C.M. and De Angelis, M. (2011). Stuck in the middle: The psychophysics of goal pursuit. Psychological science, 22(5), pp.607-612.

Camerer, C., Babcock, L., Loewenstein, G., \& Thaler, R. (1997). "Labor supply of New York City cabdrivers: One day at a time”. The Quarterly Journal of Economics, 112(2), 407-441.

Craig, A. C., Garbarino, E., Heger, S. A., \& Slonim, R. (2017). "Waiting to give: stated and revealed preferences”. Management Science, 63(11), 3672-3690.

Cryder, C. E., Loewenstein, G., \& Seltman, H. (2013). “Goal gradient in helping behavior”. Journal of Experimental Social Psychology, 49(6), 1078-1083.

Davies, G. and Diver, T. (2020): "UK coronavirus lockdown: what are the new rules and what does it mean for daily life?”. The Telegraph, March 252020. https://www.telegraph.co.uk/news/2020/03/25/uk-coronavirus-lockdown-rules-advicegovernment/

Durante, R. and Gulino, G., 2020. Asocial capital: Civic culture and social distancing during COVID19.

Exley, C. L., \& Terry, S. J. (2019). "Wage elasticities in working and volunteering: The role of reference points in a laboratory study”. Management Science, 65(1), 413-425.

Ferguson, N., Laydon, D., Nedjati Gilani, G., Imai, N., Ainslie, K., Baguelin, M., Bhatia, S., Boonyasiri, A., Cucunuba Perez, Z.U.L.M.A., Cuomo-Dannenburg, G. and Dighe, A. (2020). "Report 9: Impact of non-pharmaceutical interventions (NPIs) to reduce COVID19 mortality and healthcare demand". Imperial College London.

France 24 (2020): “France's coronavirus death toll tops 1,000, lockdown likely to be extended”. March 23 2020. https://www.france24.com/en/20200324-france-s-scientific-council-says-coronaviruslockdown-should-last-at-least-six-weeks

Galluzzo, M. (2020). "Coronavirus, Conte: «Blocco totale e chiusura delle scuole saranno prorogati. Tutela per le aziende strategiche»”, Il Corriere della Sera, March 20, 2020. https://www.corriere.it/politica/20 marzo 19/coronavirus-conte-blocco-totale-chiusura-scuolesaranno-prorogati-tutela-le-aziende-strategiche-33d5ea34-695a-11ea-913c-55c2df06d574.shtml

Heath, C., Larrick, R.P. and Wu, G. (1999). “Goals as reference points”. Cognitive psychology, 38(1), pp.79-109. 
Hessler, P. (2020): Life on Lockdown in China, The New Yorker, March 23, 2020. https://www.newyorker.com/magazine/2020/03/30/life-on-lockdown-in-china

Huang, S.C., Zhang, Y. and Broniarczyk, S.M. (2012). So near and yet so far: The mental representation of goal progress. Journal of Personality and Social Psychology, 103(2), p.225.

Jensen, U. T. (2020). "Is self-reported social distancing susceptible to social desirability bias? Using the crosswise model to elicit sensitive behaviors". Journal of Behavioral Public Administration, $3(2)$.

Kahneman, D., and Tversky, A. (1979). "Prospect theory: An analysis of decision under risk. In Handbook of the fundamentals of financial decision making: Part I" (pp. 99-127). Econometrica, 47(2), 263-292.

Kelly, Theresa F; Milkman, Katherine L (2013). “Escalation of Commitment”. In Kessler, Eric H (ed.). Encyclopedia of Management Theory. Thousand Oaks, CA: Sage Publications, pp. 256-259. doi:10.4135/9781452276090.n78.

Köszegi, B., \& Rabin, M. (2006). “A model of reference-dependent preferences”. The Quarterly Journal of Economics, 121(4), 1133-1165.

Louro, M.J., Pieters, R. and Zeelenberg, M. (2007). “Dynamics of multiple-goal pursuit”. Journal of personality and social psychology, 93(2), p.174.

Maharaj, S. and Kleczkowski, A. (2012). "Controlling epidemic spread by social distancing: Do it well or not at all”. BMC Public Health, 12(1), p.679.

Papageorge, N.W., Zahn, M.V., Belot, M., van den Broek-Altenburg, E., Choi, S., Jamison, J.C. and Tripodi, E. (2020). Socio-Demographic Factors Associated with Self-Protecting Behavior during the COVID-19 Pandemic (No. 13333). Institute of Labor Economics (IZA).

Staw, B.M. (1981). "The escalation of commitment to a course of action”. Academy of management Review, 6(4), pp.577-587.

Thakral, N., \& Tô, L. T. (2017). "Daily labor supply and adaptive reference points". American Economic Review.

Tversky, A., and Kahneman D. (1992). "Advances in prospect theory: Cumulative representation of uncertainty." Journal of Risk and uncertainty 5, no. 4, 297-323.

Watanabe, T. and Yabu, T. (2020). “Japan's Voluntary Lockdown”. Covid Economics: Vetted and RealTime Papers, Issue 46, 1-31, 1 September 2020, CEPR Press.

Wenner, L. M. (2015). "Expected prices as reference points-theory and experiments”. European Economic Review, 75, 60-79.

Yang, S. and Kubota, Y. (2020). "Spreading Coronavirus Prompts Lockdown of More Chinese Cities”. The Wall Street Journal, January 23, 2020. https://www.wsj.com/articles/spreading-coronavirusforces-lockdown-of-another-chinese-city-11579774393 
APPENDIX 


\section{Appendix A: Detailed chronology of COVID-19 events and policy responses in Italy}

The Government of Italy declared a six-month long state of emergency to respond to the COVID-19 outbreak on January 31, 2020, after blocking air traffic from China the day before. Cases of contagion in the northern regions of the country rose more rapidly than in the rest of the country, which led to a series of national and local government measures being implemented concurrently. In the most affected region, Lombardia, the government suspended most public activities, including economic and educational ones, in ten villages in Lombardia, with similar measures being adopted in one village in Veneto region the following day. On February 23, further tightening of restrictions in these villages were applied, including a prohibition to access or leave the area or hold any type of meeting for the following fourteen days.

On the same day, several regions in the North of Italy suspended upcoming public events, and closed schools and museums, until Sunday, March 1 for Lombardy, Veneto, Friuli-Venezia Giulia, and Emilia Romagna, and February 29 for Piemonte, with the provision that the deadline might change as the “epidemiological scenarios” developed.

On February 24, other northern regions adopted similar isolation measures, such as Liguria and the Province of Trento, followed by the central region of Marche (announcing a preliminary deadline for March 4). On March 1, the Government issued a decree suspending public events and closing schools until March 8 in Lombardia, Veneto and Emilia Romagna and in some provinces of Marche and Liguria. On March 4, the closure of schools was extended to the whole country until March 15.

On March 8, the government implemented a total lockdown and banned individual movements with an exception for work or health reasons or for necessity (e.g. purchasing of food and medicines) in the whole of Lombardia and in selected provinces in Emilia Romagna, Veneto, Marche and Piemonte, for a total of 14 provinces in the North of the country. The following day the government extended these measures to the whole country. These restrictions were announced to remain in place until April 3. On March 11th, the government also ordered the closure of most retail shops until March 25, with the exception of grocery shops and pharmacies. This included restaurants, bars, and most personal services (e.g. hairdressers). 
On March 22, the government announced that the originally scheduled end date for the closure of commercial activities (March 11) was extended to April 3, and further suspended commercial and industrial activities, and prohibited individual movements outside the town of domicile, with an exception of work or health reasons or for absolute necessity.

On April 1, the government extended a total lockdown to the whole country until 13 April, and on April 10 it was prolonged until May 3.

On April 26, the government announced a starter plan for the so-called "phase 2", that would start from 4 May. Due to the "Phase 2", movements across regions would still be forbidden, while the ones between municipalities would be allowed only for work and health reasons, as well as for visits to relatives. Re-opening of manufacturing industries and construction sites are allowed too.

On May 13, the government announced schools would remain closed until September.

On May 16, the Prime Minister announced the Government plan for the easing of restrictions.

Due to the plan, most businesses could reopen, and free movement was granted to all citizens within their Region; inter-regional travel was not permitted, unless it is for absolute necessity. Swimming pools, gyms and then theatres and cinemas could also reopen.

On June 3, the government allowed unrestricted travel to and from EU countries and between Italy's regions. The inter-regional and foreign travel ban remained in place until after Italy's June 2 Republic Day holiday, avoiding any mass travel over that long-holiday weekend. 
TABLE A1. Timeline of COVID-19 epidemic and policy responses in Italy

Date

Event

30-Jan-20

Italy closes flights from China

31-Jan-20

First two cases of COVID-19 diagnosed in Rome

31-Jan-20

Government declares state of emergency

21-Feb-20

First cases of community transmission reported in Lombardia and Veneto; first

COVID-19 death (in Vo', Veneto)

21-Feb-20

Most public activities suspended in outbreak areas in Lombardia and (the following day) in Veneto

23-Feb-20

Complete lockdown of outbreak areas in Lombardia and Veneto

24-Feb-20

Schools closed in Lombardia, Veneto, Friuli-Venezia Giulia, Emilia Romagna and (on the following days) Liguria and Marche

4-Mar-20

Schools closure extended to the whole country, announced until March 15

8-Mar-20

Lockdown ("stay at home” measures) declared for Lombardia and 14 Provinces in Veneto, Emilia Romagna, Piemonte and Marche

9-Mar-20

Lockdown ("stay at home” measures) extended to the whole country until April $3^{\text {rd }}$; schools closure extended to the whole country, announced until April $3^{\text {rd }}$ 

pharmacies), restaurants and bars, as well as most personal services until March $25^{\text {th }}$

19-Mar-20

22-Mar-20

1-Apr-20

10-Apr-20

26-Apr-20

4- May-20

13-May-20

16-May-20

3-Jun-20
Italy surpasses China as the country with the most reported COVID-19 deaths

Government suspended all non-essential economic activities until April 3rd. It also prohibited individual movements outside people's town of domicile (with the exception of work- and health-related reasons or in case of absolute urgency). All these measures are put in place until April 3

Lockdown extended to the whole country until April 13

Lockdown extended to the whole country until May 3

Government announced a starter plan for the so-called "phase 2", that would start from May 4

"Phase 2" started: movements across regions would still be forbidden, while the ones between municipalities would be allowed only for work and health reasons, as well as for visits to relatives. Re-opening of manufacturing industries and construction sites

Government announced schools would remain closed until September The Prime Minister announced the Government plan for the easing of restrictions. Due to the plan, most businesses could reopen, and free movement was granted to all citizens within their Region; movement across Regions was still banned for nonessential motives.

Government allows travels to and from Italy and between the country's regions 


\section{Appendix B: Survey questions}

List of survey questions.

Original Italian (English translation below)

1. Per prevenire il contagio, quali di questi comportamenti quotidiani sta adottando?

[Rotazione tipo: random]

a. mi lavo le mani molto spesso

b. vado in giro con la mascherina

c. non stringo più la mano a nessuno

d. cerco di stare a distanza dalle persone

e. non frequento luoghi affollati

f. vado il meno possibile nei supermercati

g. non mi incontro più con gli amici

h. non mi incontro più con i parenti che non vivono con me

i. non esco di casa salvo urgenze

[Fine rotazione]

j. $\quad$ nessuno di questi

k. preferisco non rispondere

2. Il Governo ha annunciato una serie di misure temporanee di autoisolamento per fronteggiare l'emergenza coronavirus, il cosiddetto decreto "io sto a casa". Si ricorda fino a che data resteranno in vigore queste misure?

[Inserire data: $\mathrm{dd} / \mathrm{mm} / \mathrm{yyyy}]$

3. La data di scadenza delle misure "io sto a casa" annunciata dal Governo è il [3 aprile/13 aprile/3 maggio]. Secondo Lei queste misure:

a. Termineranno nella data prevista

b. Verranno prorogate di qualche settimana

c. Verranno prorogate di qualche mese 
d. Verranno prorogate a tempo indefinito, fino a quando sarà ritenuto necessario

[Le prossime tre domande vengono presentate in ordine casuale]

4. Se le misure di autoisolamento dovessero essere prorogate di qualche settimana oltre la scadenza del [3 aprile/13 aprile/3 maggio], quale di queste opzioni descrive meglio ciò che lei pensa di fare:

a. Aumenterei significativamente il mio autoisolamento

b. Aumenterei in qualche misura il mio autoisolamento

c. Continuerei con i miei comportamenti attuali

d. Ridurrei in qualche misura il mio autoisolamento

e. Potrei decidere di non rispettare più le regole

5. Se le misure di autoisolamento dovessero essere prorogate di qualche mese oltre la scadenza del [3 aprile/13 aprile/3 maggio], quale di queste opzioni descrive meglio ciò che lei pensa di fare:

a. Aumenterei significativamente il mio autoisolamento

b. Aumenterei in qualche misura il mio autoisolamento

c. Continuerei con i miei comportamenti attuali

d. Ridurrei in qualche misura il mio autoisolamento

e. Potrei decidere di non rispettare più le regole

6. Se le misure di autoisolamento dovessero essere prorogate a tempo indefinito oltre la scadenza del [3 aprile/13 aprile/3 maggio],fino a quando sarà ritenuto necessario, quale di queste opzioni descrive meglio ciò che lei pensa di fare:

a. Aumenterei significativamente il mio autoisolamento

b. Aumenterei in qualche misura il mio autoisolamento

c. Continuerei con i miei comportamenti attuali

d. Ridurrei in qualche misura il mio autoisolamento

e. Potrei decidere di non rispettare più le regole

[Fine randomizzazione] 


\section{ENGLISH TRANSLATION}

1. To prevent contagion, which of these everyday behaviors are you adopting? [items a) through i) presented in random order]
a) I very often wash my hands
b) I walk around with a mask
c) I don't shake hands anymore
d) I try to keep a safe distance from people
e) I do not go to crowded places
f) I go to supermarkets as seldom as possible
g) I no longer meet with friends
h) I no longer meet with relatives who do not live with me
i) I do not leave home except in an emergency
j) None of these
k) I prefer not to answer

2. The Government announced and enacted a series of policies to address the COVID19 emergency, in particular the presidential decree known as "I stay at home". Do you remember until what date the social isolation measures are in place?

[enter date here]

3. The "Stay at home" measures are set to end on [April 3 / April 13 / May 3]. In your opinion, these measures:

a. will actually end on the announced date

b. will be extended by a few additional weeks

c. will be extended by a few additional months

d. will be extended indefinitely, until deemed necessary

[the next three questions three questions are in random order for each respondent] 
4. If the self-isolation measures are extended by a few additional weeks after [April 3 / April 13 / May

3], which of these options best represents what you plan to do:

a. I would significantly increase my isolation

b. I would somewhat increase my isolation

c. I would continue in my current behavior

d. I would somewhat reduce my isolation

e. I might decide not to comply with the rules

5. If the self-isolation measures are extended by a few additional months after [April 3 / April 13 / May 3], which of these options best represents what you plan to do:

a. I would significantly increase my isolation

b. I would somewhat increase my isolation

c. I would continue in my current behavior

d. I would somewhat reduce my isolation

e. I might decide not to comply with the rules

6. If the self-isolation measures are extended indefinitely after [April 3 / April 13 / May 3], until deemed necessary, which of these options best represents what you plan to do:

a. I would significantly increase my isolation

b. I would somewhat increase my isolation

c. I would continue in my current behavior

d. I would somewhat reduce my isolation

e. I might decide not to comply with the rules 


\section{Appendix C: Additional Figures and Tables}

TABLE C1: Socio-demographic characteristics, by sub-group

\begin{tabular}{lcccc}
\hline & $\begin{array}{c}\text { Respondents } \\
\text { Age 18-59 }\end{array}$ & $\begin{array}{c}\text { Respondents } \\
\text { Age 60+ }\end{array}$ & $\begin{array}{c}\text { Respondents in Red } \\
\text { Zone regions }\end{array}$ & $\begin{array}{c}\text { Respondents in the } \\
\text { rest of the country }\end{array}$ \\
\cline { 2 - 3 } Women & $50.3 \%$ & $55.3 \%$ & $51.7 \%$ & $52.4 \%$ \\
Age & 41.0 & 70.7 & 50.5 & 51.0 \\
Completed high school & $65.7 \%$ & $66.1 \%$ & $67.3 \%$ & $63.6 \%$ \\
College degree & $23.8 \%$ & $10.7 \%$ & $19.5 \%$ & $19.5 \%$ \\
Lives alone & $12.6 \%$ & $17.2 \%$ & $14.1 \%$ & $14.2 \%$ \\
Lives with parents & $18.2 \%$ & $0.3 \%$ & $12.4 \%$ & $12.2 \%$ \\
Married & $57.2 \%$ & $73.7 \%$ & $63.2 \%$ & $61.7 \%$ \\
Has children & $51.5 \%$ & $88.2 \%$ & $64.4 \%$ & $62.3 \%$ \\
Employed & $68.4 \%$ & $18.1 \%$ & $49.8 \%$ & $54.6 \%$ \\
Economically comfortable & $45.3 \%$ & $44.2 \%$ & $42.7 \%$ & $48.5 \%$ \\
Facing economic difficulties & $54.7 \%$ & $55.8 \%$ & $57.3 \%$ & $51.5 \%$ \\
Compliance with social-isolation measures & 4.2 & 4.4 & 4.2 & 4.3 \\
Adopting all social-isolation measures & $44.0 \%$ & $50.5 \%$ & $45.0 \%$ & $47.7 \%$ \\
Age 60+ & & & $32.3 \%$ & $33.6 \%$ \\
Lives in Red Zone & $39.2 \%$ & $40.6 \%$ & & $43.4 \%$ \\
Lives in Lombardia & $16.3 \%$ & $19.2 \%$ & & 1,049 \\
$\mathrm{~N}$ & 1,835 & 862 & 1,648 & \\
\hline \hline
\end{tabular}

Notes: The table reports the average age of the participants belonging to various sub-categories. Red Zone includes residents of the following regions: Emilia Romagna, Lombardia, Marche, Piemonte, Veneto. The variable "economically comfortable" is equal to 1 if respondents reported that their household income allows them to live "comfortably" or "without concerns", whereas "Facing economic difficulties" is equal to 1 if the respondent replied that they "are having economic difficulties", "make to the end of the month with much struggling", or "are poor and their income does not allow them to make it to the end of the month". "Compliance with social-isolation measures" is the number of socialisolation measures respondents report having adopted, and "adopting all social-isolation measures is a dummy variable indicating respondents who reported adopting all recommended measures (see Appendix Table C2 for details). We used sampling weights to adjust these statistics. 
TABLE C2: Compliance with COVID-19 preventive and social distancing measures

$\%$ of respondents adopting each preventive and social distancing measure

\begin{tabular}{lcc} 
& Wave 1 & Wave 3 \\
\cline { 2 - 3 } (i) I wash my hands very often & $78.6 \%$ & $69.3 \%$ \\
(ii) I walk around with a mask & $42.1 \%$ & $69.5 \%$ \\
(iii) I don't shake hands anymore & $72.1 \%$ & $64.0 \%$ \\
(iv) I try to keep a safe distance from people & $74.0 \%$ & $68.5 \%$ \\
(v) I do not go to crowded places & $75.2 \%$ & $68.8 \%$ \\
(vi) I go to supermarkets as seldom as possible & $71.1 \%$ & $65.7 \%$ \\
(vii) I no longer meet with friends & $72.5 \%$ & $64.7 \%$ \\
(viii) I no longer meet with relatives & $67.1 \%$ & $59.5 \%$ \\
(ix) I do not leave home except in an emergency & $80.2 \%$ & $75.4 \%$ \\
None of these & $0.9 \%$ & $1.1 \%$ \\
I prefer not to answer & $1.3 \%$ & $1.2 \%$ \\
& & \\
& & \\
\% adopting all nine preventive and social distancing measures (i)-(ix)
\end{tabular}

\begin{tabular}{cc} 
Wave 1 & Wave 3 \\
\hline Full sample & Full sample \\
$29.1 \%$ & $37.6 \%$
\end{tabular}

$\%$ adopting all six social distancing measures (iv)-(ix)

\begin{tabular}{cc} 
Wave 1 & Wave 3 \\
\hline Full sample & Full sample \\
$49.9 \%$ & $42.2 \%$
\end{tabular}

N. respondents

885

904

Notes: We used sampling weights (provided by SWG) to compute these statistics. 
TABLE C3: Compliance with COVID-19 preventive and social distancing measures, by sub-groups

$\%$ of respondents adopting each preventive and social distancing measure

(i) I very often wash my hands

Wave 1

Wave 3

(ii) I walk around with a mask

\begin{tabular}{cc}
\hline 760 years old & Red zone \\
$84.3 \%$ & $74.8 \%$
\end{tabular}

$>60$ years old Red zone

(iii) I don't shake hands anymore

$47.5 \%$

$41.1 \%$

$70.7 \%$

$66.1 \%$

(iv) I try to keep a safe distance from people

$75.6 \%$

$75.0 \%$

$71.4 \%$

$71.4 \%$

$77.0 \%$

$75.8 \%$

$69.5 \%$

$64.0 \%$

(v) I do not go to crowded places

$74.1 \%$

$78.0 \%$

$70.7 \%$

$68.8 \%$

(vi) I go to supermarkets as seldom as possible

$71.4 \%$

$73.2 \%$

$69.1 \%$

$68.6 \%$

(vii) I no longer meet with friends

$73.5 \%$

$72.0 \%$

$69.5 \%$

$65.0 \%$

(viii) I no longer meet with relatives

$70.8 \%$

$66.9 \%$

$64.2 \%$

$63.9 \%$

(ix) I do not leave home except in an emergency

$88.3 \%$

$78.4 \%$

$59.3 \%$

$61.9 \%$

None of these

$1.6 \%$

$1.6 \%$

$78.5 \%$

$80.3 \%$

I prefer not to answer

$0.1 \%$

$0.3 \%$

$0.0 \%$

$1.1 \%$

$1.6 \%$

$1.5 \%$

$\%$ adopting all nine preventive and social distancing measures (i)-(ix)

$\begin{array}{cccc}>60 \text { years old } & \text { Red zone } & >60 \text { years old } & \text { Red zone } \\ 35.9 \% & 29.2 \% & 42.3 \% & 38.6 \%\end{array}$

\% adopting all six social distancing measures (iv)-(ix)

$\begin{array}{cccc}>60 \text { years old } & \text { Red zone } & >60 \text { years old } & \text { Red zone } \\ 55.3 \% & 51.5 \% & 45.3 \% & 43.5 \%\end{array}$

N. respondents

310

355

267

353

Notes: We used sampling weights (provided by SWG) to compute these statistics. 
TABLE C4: Knowledge of end date of current stay-at-home measures

\begin{tabular}{lccccc}
\hline & Full sample & Wave 1 & Wave 2 & Wave 3 \\
\cline { 2 - 3 } \% reporting correct date: & & & & \\
Overall & $77.2 \%$ & $73.5 \%$ & $64.7 \%$ & $93.4 \%$ \\
Age 18-59 & $76.9 \%$ & $76.5 \%$ & $61.5 \%$ & $92.4 \%$ \\
Age 60+ & $77.6 \%$ & $67.3 \%$ & $71.0 \%$ & $95.5 \%$ \\
Red zone residents & $77.3 \%$ & $77.0 \%$ & $62.7 \%$ & $92.8 \%$ \\
Residents outside red zone & $77.2 \%$ & $73.5 \%$ & $64.7 \%$ & $93.4 \%$ \\
\hline
\end{tabular}

TABLE C5: Expected end date of self-isolation measures, by sub-groups

$\%$ of respondents reporting the stay-athome measures would (be) ...

Wave $1 \quad$ Wave 2 Wave 3

End as planned

Extended by a few weeks

Extended by a few months

Extended indefinitely

End as planned

Extended by a few weeks

Extended by a few months

Extended indefinitely

End as planned

Extended by a few weeks

Extended by a few months

Extended indefinitely

End as planned

Extended by a few weeks

Extended by a few months

Extended indefinitely

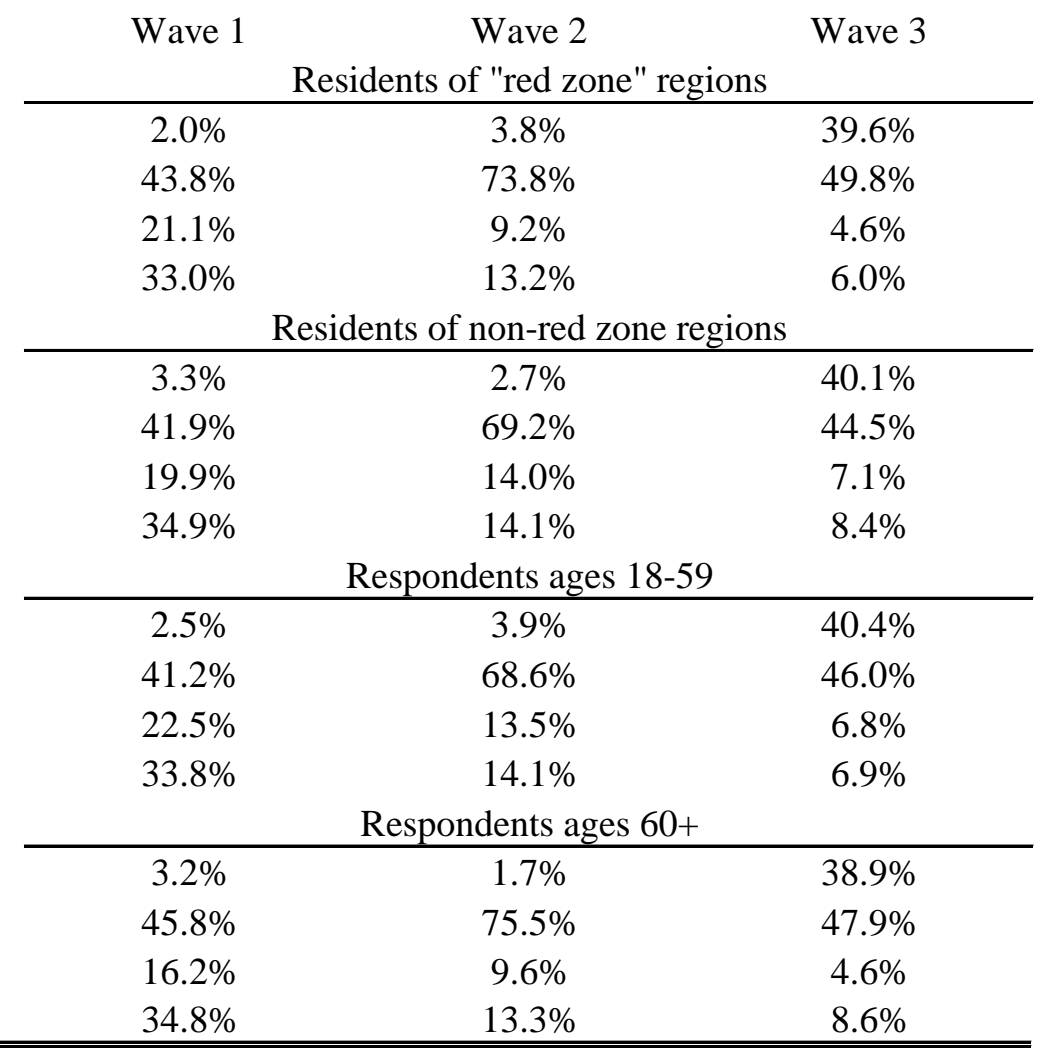


TABLE C6: Self-isolation intentions, controlling for baseline levels of compliance with social-

isolation measures

\begin{tabular}{|c|c|c|c|c|c|c|c|}
\hline \multirow{2}{*}{\multicolumn{2}{|c|}{ Option: }} & \multicolumn{2}{|c|}{ (1) } & \multicolumn{2}{|c|}{ (2) } & \multicolumn{2}{|c|}{ (3) } \\
\hline & & $\begin{array}{l}\text { Increase } \\
\text { compliance }\end{array}$ & $\begin{array}{c}\text { Reduce } \\
\text { compliance }\end{array}$ & $\begin{array}{l}\text { Increase } \\
\text { compliance }\end{array}$ & $\begin{array}{l}\text { Reduce } \\
\text { compliance }\end{array}$ & $\begin{array}{l}\text { Increase } \\
\text { compliance }\end{array}$ & $\begin{array}{c}\text { Reduce } \\
\text { compliance }\end{array}$ \\
\hline Scenario & Until Needed & $\begin{array}{c}1.339^{* *} \\
(0.158) \\
1.704^{* * *} \\
(0.318)\end{array}$ & $\begin{array}{c}1.070 \\
(0.148) \\
0.907 \\
(0.191)\end{array}$ & $\begin{array}{c}1.293^{* *} \\
(0.149) \\
1.707 * * * \\
(0.315)\end{array}$ & $\begin{array}{c}1.078 \\
(0.152) \\
0.901 \\
(0.194)\end{array}$ & $\begin{array}{c}1.267^{* *} \\
(0.118) \\
1.362^{* *} \\
(0.195)\end{array}$ & $\begin{array}{c}1.387^{* * *} \\
(0.135) \\
1.491^{* * *} \\
(0.174)\end{array}$ \\
\hline $\begin{array}{r}\text { Length of } \\
\text { hypothesized } \\
\text { extension, relative to } \\
\text { expectations: }\end{array}$ & $\begin{array}{c}\text { Longer } \\
\text { Much longer }\end{array}$ & & & $\begin{array}{c}1.373 \\
(0.320) \\
1.091 \\
(0.155) \\
0.837 \\
(0.100) \\
0.553^{* * *} \\
(0.112)\end{array}$ & $\begin{array}{c}0.831 \\
(0.227) \\
0.915 \\
(0.169) \\
1.539 * * * \\
(0.230) \\
2.287^{* * *} \\
(0.544)\end{array}$ & & \\
\hline $\begin{array}{r}\text { Length of } \\
\text { hypothesized }\end{array}$ & Shorter & & & & & $\begin{array}{l}1.107 \\
(0.162)\end{array}$ & $\begin{array}{c}0.934 \\
(0.174)\end{array}$ \\
\hline $\begin{array}{r}\text { extension relative to } \\
\text { expectations * } \\
\text { expectations }\end{array}$ & $\begin{array}{l}\text { Longer * Expect lockdown to } \\
\text { end on announced date } \\
\text { Longer * Expect lockdown to } \\
\text { be extended by a few weeks } \\
\text { Longer* Expect lockdown to } \\
\text { be extended by a few months }\end{array}$ & & & & & $\begin{array}{c}0.676 \\
(0.182) \\
0.711^{* *} \\
(0.109) \\
1.057 \\
(0.253)\end{array}$ & $\begin{array}{c}2.528 * * * \\
(0.567) \\
1.216 \\
(0.187) \\
1.026 \\
(0.283)\end{array}$ \\
\hline Compliance & & & & $\begin{array}{c}0.666^{* *} \\
(0.108)\end{array}$ & $\begin{array}{c}0.663^{* *} \\
(0.106)\end{array}$ & $\begin{array}{c}0.673^{* *} \\
(0.110)\end{array}$ & $\begin{array}{c}0.663^{* *} \\
(0.107)\end{array}$ \\
\hline Wave: & Wave 3 & $\begin{array}{c}0.702^{* *} \\
(0.125)\end{array}$ & $\begin{array}{c}1.765^{* * *} \\
(0.314)\end{array}$ & $\begin{array}{c}0.628^{* * *} \\
(0.110)\end{array}$ & $\begin{array}{c}1.720^{* * *} \\
(0.312)\end{array}$ & $\begin{array}{c}0.612^{* * *} \\
(0.109)\end{array}$ & $\begin{array}{l}1.515^{* *} \\
(0.300)\end{array}$ \\
\hline $\begin{array}{r}\text { Adjusted Wald test } \\
\text { of differences }\end{array}$ & $\begin{array}{r}\text { Longer - Shorter } \\
\text { Much longer - much shorter }\end{array}$ & $\begin{array}{l}0.165 \\
0.017\end{array}$ & $\begin{array}{l}0.016 \\
0.02\end{array}$ & $\begin{array}{c}1.76 \\
5.58^{* *}\end{array}$ & $\begin{array}{l}5.13^{* *} \\
5.27 * *\end{array}$ & & \\
\hline & $\begin{array}{r}\text { Observations } \\
\text { F-statistic } \\
\text { N. respondents }\end{array}$ & & $\begin{array}{l}280 \\
5.4 \\
760\end{array}$ & & $\begin{array}{l}29 \\
4 \\
43\end{array}$ & & $\begin{array}{l}229 \\
.5 \\
43\end{array}$ \\
\hline
\end{tabular}

Notes: The baseline option is "maintain current behavior", the omitted scenario is "a few weeks", and the omitted wave is Wave 1. We report the estimates as relative risk ratios. Each respondent selected one option from each of three questions, therefore there are up to three observations per individual in the regression sample. The control variables include gender, age, education, whether the respondent lives alone or with her/his parents, marital status, whether the respondent has children, whether s/he is currently employed, whether the respondents' household is currently facing economic difficulties, and whether they live in one of the "Red Zone" regions. "Compliance" is an indicator variable for whether respondents reported adopting all six social-isolation emasures listed in the survey (see Appendix Table $\mathrm{C} 2$ ). The regressions include sampling weights. Linearized standard errors are in parenthesis. $* * *$ $\mathrm{p}<0.01, * * \mathrm{p}<0.05, * \mathrm{p}<0.1$ 
TABLE C7: Self-isolation intentions: Multinomial Logit estimates, alternative specification

\begin{tabular}{|c|c|c|c|c|c|}
\hline & & \multicolumn{2}{|c|}{ (1) } & \multicolumn{2}{|c|}{ (2) } \\
\hline & & $\begin{array}{l}\text { Increase } \\
\text { compliance }\end{array}$ & $\begin{array}{c}\text { Reduce } \\
\text { compliance }\end{array}$ & $\begin{array}{l}\text { Increase } \\
\text { compliance }\end{array}$ & $\begin{array}{c}\text { Reduce } \\
\text { compliance }\end{array}$ \\
\hline \multirow[t]{2}{*}{ Scenario } & A few months & $\begin{array}{c}1.254 * * * \\
(0.102)\end{array}$ & $\begin{array}{c}1.256^{* *} \\
(0.130)\end{array}$ & $\begin{array}{c}1.059 \\
(0.0716)\end{array}$ & $\begin{array}{c}1.446 * * * \\
(0.112)\end{array}$ \\
\hline & Until Needed & $\begin{array}{l}1.328^{* *} \\
(0.159)\end{array}$ & $\begin{array}{l}1.302^{* *} \\
(0.168)\end{array}$ & $\begin{array}{c}0.997 \\
(0.0946)\end{array}$ & $\begin{array}{c}1.521^{* * *} \\
(0.137)\end{array}$ \\
\hline \multirow[t]{3}{*}{ Expectations } & A few weeks & & & $\begin{array}{c}0.766 \\
(0.192)\end{array}$ & $\begin{array}{c}0.475 * * * \\
(0.0917)\end{array}$ \\
\hline & A few months & & & $\begin{array}{c}1.169 \\
(0.347)\end{array}$ & $\begin{array}{c}0.508^{* *} \\
(0.137)\end{array}$ \\
\hline & Until needed & & & $\begin{array}{c}1.334 \\
(0.414)\end{array}$ & $\begin{array}{l}0.515^{* *} \\
(0.171)\end{array}$ \\
\hline $\begin{array}{l}\text { Length of } \\
\text { hypothesized }\end{array}$ & Shorter & $\begin{array}{c}1.160 \\
(0.143)\end{array}$ & $\begin{array}{c}1.049 \\
(0.186)\end{array}$ & $\begin{array}{c}0.827^{*} \\
(0.0865)\end{array}$ & $\begin{array}{l}0.980 \\
(0.147)\end{array}$ \\
\hline $\begin{array}{l}\text { extension, relative to } \\
\text { expectations: }\end{array}$ & Longer & $\begin{array}{c}0.811^{*} \\
(0.0930)\end{array}$ & $\begin{array}{c}1.679 * * * \\
(0.246)\end{array}$ & $\begin{array}{c}1.021 \\
(0.0928)\end{array}$ & $\begin{array}{l}1.305^{* *} \\
(0.150)\end{array}$ \\
\hline \multirow[t]{2}{*}{ Wave } & Wave 2 & $\begin{array}{l}0.808 \\
(0.127)\end{array}$ & $\begin{array}{c}0.841 \\
(0.160)\end{array}$ & $\begin{array}{l}0.853 \\
(0.137)\end{array}$ & $\begin{array}{l}0.881 \\
(0.172)\end{array}$ \\
\hline & Wave 3 & $\begin{array}{c}0.636^{* * *} \\
(0.108)\end{array}$ & $\begin{array}{c}1.964^{* * *} \\
(0.327)\end{array}$ & $\begin{array}{c}0.616^{* *} \\
(0.116)\end{array}$ & $\begin{array}{l}1.593^{* *} \\
(0.306)\end{array}$ \\
\hline \multirow{5}{*}{$\begin{array}{l}\text { Adjusted Wald test of } \\
\text { differences (F-stat) }\end{array}$} & Longer - Shorter & $3.27^{*}$ & $3.39 *$ & 1.82 & 2.16 \\
\hline & Control variables & \multicolumn{2}{|c|}{ Yes } & \multicolumn{2}{|c|}{ Yes } \\
\hline & Observations & \multicolumn{2}{|c|}{7,917} & \multicolumn{2}{|c|}{7,917} \\
\hline & F-statistic & \multicolumn{2}{|c|}{6.4} & \multicolumn{2}{|c|}{6.5} \\
\hline & N. respondents & \multicolumn{2}{|c|}{2,639} & \multicolumn{2}{|c|}{2,639} \\
\hline
\end{tabular}

Notes: The baseline option is "maintain current behavior", the omitted scenario is "a few weeks", and the omitted wave is Wave 1. We report the estimates as relative risk ratios. Each respondent selected one option from each of three questions, therefore there are up to three observations per individual in the regression sample. The control variables include gender, age, education, whether the respondent lives alone or with her/his parents, marital status, whether the respondent has children, whether s/he is currently employed, whether the respondents' household is currently facing economic difficulties, and whether they live in one of the "Red Zone" regions. The regressions include sampling weights. Linearized standard errors are in parenthesis. ${ }^{* * *} \mathrm{p}<0.01,{ }^{* *} \mathrm{p}<0.05,{ }^{*} \mathrm{p}<0.1$ 
TABLE C8: Self-isolation intentions: Multinomial Logit estimates, by area and age

\begin{tabular}{|c|c|c|c|c|c|c|c|c|c|}
\hline & \multirow[t]{2}{*}{ Sample } & \multicolumn{2}{|c|}{$\begin{array}{l}\text { Red zone } \\
\text { (1) }\end{array}$} & \multicolumn{2}{|c|}{$\begin{array}{l}\text { Outside red zone } \\
\text { (2) }\end{array}$} & \multicolumn{2}{|c|}{$\begin{array}{c}\text { Ages } 18-58 \\
\text { (3) }\end{array}$} & \multicolumn{2}{|c|}{$\begin{array}{c}\text { Ages 60+ } \\
\text { (4) }\end{array}$} \\
\hline & & $\begin{array}{c}\text { Increase } \\
\text { compliance }\end{array}$ & $\begin{array}{c}\text { Reduce } \\
\text { compliance }\end{array}$ & $\begin{array}{c}\text { Increase } \\
\text { compliance }\end{array}$ & $\begin{array}{c}\text { Reduce } \\
\text { compliance }\end{array}$ & $\begin{array}{c}\text { Increase } \\
\text { compliance }\end{array}$ & $\begin{array}{c}\text { Reduce } \\
\text { compliance }\end{array}$ & $\begin{array}{c}\text { Increase } \\
\text { compliance }\end{array}$ & $\begin{array}{c}\text { Reduce } \\
\text { compliance }\end{array}$ \\
\hline \multirow[t]{3}{*}{ Scenario } & A few months & $\begin{array}{c}1.751^{* * *} \\
(0.304)\end{array}$ & $\begin{array}{c}1.302 \\
(0.244)\end{array}$ & $\begin{array}{c}1.106 \\
(0.134)\end{array}$ & $\begin{array}{c}1.186 \\
(0.208)\end{array}$ & $\begin{array}{c}1.387^{* * *} \\
(0.170)\end{array}$ & $\begin{array}{c}1.163 \\
(0.159)\end{array}$ & $\begin{array}{c}1.136 \\
(0.191)\end{array}$ & $\begin{array}{c}1.336 \\
(0.370)\end{array}$ \\
\hline & Until Needed & $\begin{array}{c}2.280 * * * \\
(0.628)\end{array}$ & $\begin{array}{c}1.026 \\
(0.296)\end{array}$ & $\begin{array}{c}1.252 \\
(0.247)\end{array}$ & $\begin{array}{c}1.137 \\
(0.317)\end{array}$ & $\begin{array}{l}1.538^{* *} \\
(0.297)\end{array}$ & $\begin{array}{c}0.979 \\
(0.209)\end{array}$ & $\begin{array}{l}1.514 \\
(0.435)\end{array}$ & $\begin{array}{c}1.276 \\
(0.566)\end{array}$ \\
\hline & Much shorter & $\begin{array}{c}2.565^{* * *} \\
(0.778)\end{array}$ & $\begin{array}{c}0.857 \\
(0.361)\end{array}$ & $\begin{array}{c}0.961 \\
(0.239)\end{array}$ & $\begin{array}{l}1.135 \\
(0.395)\end{array}$ & $\begin{array}{l}1.497^{*} \\
(0.345)\end{array}$ & $\begin{array}{c}0.720 \\
(0.211)\end{array}$ & $\begin{array}{l}1.214 \\
(0.424)\end{array}$ & $\begin{array}{l}1.682 \\
(0.803)\end{array}$ \\
\hline \multirow{3}{*}{$\begin{array}{l}\text { Length of } \\
\text { hypothesized } \\
\text { extension, relative to } \\
\text { expectations: }\end{array}$} & Shorter & $\begin{array}{l}1.528 * * \\
(0.301)\end{array}$ & $\begin{array}{c}1.022 \\
(0.258)\end{array}$ & $\begin{array}{c}0.953 \\
(0.140)\end{array}$ & $\begin{array}{c}0.996 \\
(0.208)\end{array}$ & $\begin{array}{c}1.201 \\
(0.163)\end{array}$ & $\begin{array}{c}0.912 \\
(0.189)\end{array}$ & $\begin{array}{c}0.903 \\
(0.215)\end{array}$ & $\begin{array}{c}1.140 \\
(0.280)\end{array}$ \\
\hline & Longer & $\begin{array}{c}0.699 * * \\
(0.123)\end{array}$ & $\begin{array}{l}1.434^{*} \\
(0.298)\end{array}$ & $\begin{array}{c}0.968 \\
(0.123)\end{array}$ & $\begin{array}{c}1.624 * * * \\
(0.295)\end{array}$ & $\begin{array}{c}0.869 \\
(0.111)\end{array}$ & $\begin{array}{c}1.597 * * * \\
(0.236)\end{array}$ & $\begin{array}{c}0.851 \\
(0.141)\end{array}$ & $\begin{array}{c}1.485 \\
(0.430)\end{array}$ \\
\hline & Much longer & $\begin{array}{c}0.441^{* * *} \\
(0.128)\end{array}$ & $\begin{array}{r}2.010^{* *} \\
(0.630)\end{array}$ & $\begin{array}{c}0.839 \\
(0.184)\end{array}$ & $\begin{array}{c}2.085^{* *} \\
(0.633)\end{array}$ & $\begin{array}{c}0.745 \\
(0.156)\end{array}$ & $\begin{array}{c}2.219 * * * \\
(0.527)\end{array}$ & $\begin{array}{l}0.551^{*} \\
(0.170)\end{array}$ & $\begin{array}{c}1.892 \\
(0.886)\end{array}$ \\
\hline \multirow[t]{2}{*}{ Wave } & Wave 2 & $\begin{array}{c}0.798 \\
(0.206)\end{array}$ & $\begin{array}{l}0.658^{*} \\
(0.162)\end{array}$ & $\begin{array}{c}0.867 \\
(0.174)\end{array}$ & $\begin{array}{c}0.975 \\
(0.262)\end{array}$ & $\begin{array}{c}0.746 \\
(0.139)\end{array}$ & $\begin{array}{c}0.737 \\
(0.146)\end{array}$ & $\begin{array}{c}1.041 \\
(0.311)\end{array}$ & $\begin{array}{l}1.009 \\
(0.415)\end{array}$ \\
\hline & Wave 3 & $\begin{array}{c}0.703 \\
(0.207)\end{array}$ & $\begin{array}{l}1.623 * * \\
(0.394)\end{array}$ & $\begin{array}{l}0.667^{*} \\
(0.142)\end{array}$ & $\begin{array}{c}2.052^{* * *} \\
(0.509)\end{array}$ & $\begin{array}{c}0.612^{* *} \\
(0.118)\end{array}$ & $\begin{array}{c}1.783 * * * \\
(0.337)\end{array}$ & $\begin{array}{c}0.804 \\
(0.288)\end{array}$ & $\begin{array}{l}1.912^{*} \\
(0.718)\end{array}$ \\
\hline \multirow{5}{*}{$\begin{array}{l}\text { Adjusted Wald test } \\
\text { of differences } \\
\text { (F-stat) }\end{array}$} & $\begin{array}{l}\text { Longer - Shorter } \\
\text { Much longer - much shorter }\end{array}$ & $\begin{array}{l}8.06^{* * *} \\
11.14 * * *\end{array}$ & $\begin{array}{l}1.38 \\
2.01\end{array}$ & 1.11 & 2.69 & $\begin{array}{l}3.46 * \\
285 *\end{array}$ & $\begin{array}{l}7.58^{* * *} \\
6.31 * *\end{array}$ & $\begin{array}{l}1.61 \\
0.03\end{array}$ & $\begin{array}{l}0.02 \\
0.34\end{array}$ \\
\hline & Control variables & \multicolumn{2}{|c|}{ Yes } & \multicolumn{2}{|c|}{ Yes } & \multicolumn{2}{|c|}{ Yes } & \multicolumn{2}{|c|}{ Yes } \\
\hline & Observations & \multicolumn{2}{|c|}{3,108} & \multicolumn{2}{|c|}{4,809} & \multicolumn{2}{|c|}{5,364} & \multicolumn{2}{|c|}{2,553} \\
\hline & F-statistic & \multicolumn{2}{|c|}{4.1} & \multicolumn{2}{|c|}{3.8} & \multicolumn{2}{|c|}{4.7} & \multicolumn{2}{|c|}{3.4} \\
\hline & N. respondents & \multicolumn{2}{|c|}{1036} & \multicolumn{2}{|c|}{1603} & \multicolumn{2}{|c|}{1788} & \multicolumn{2}{|c|}{851} \\
\hline
\end{tabular}

Notes: The baseline option is "maintain current behavior", the omitted scenario is "a few weeks", and the omitted wave is Wave 1. We report the estimates as relative risk ratios. Each respondent selected one option from each of three questions, therefore there are up to three observations per individual in the regression sample. The control variables include gender, age, education, whether the respondent lives alone or with her/his parents, marital status, whether the respondent has children, whether s/he is currently employed, whether the respondents' household is currently facing economic difficulties, and whether they live in one of the "Red Zone" regions. The regressions include sampling weights. Linearized standard errors are in parenthesis. ${ }^{* * *} \mathrm{p}<0.01$, ${ }^{* *} \mathrm{p}<0.05,{ }^{*} \mathrm{p}<0.1$ 
FIGURE C9: Self-isolation intentions, by hypothesized duration of lockdown extension

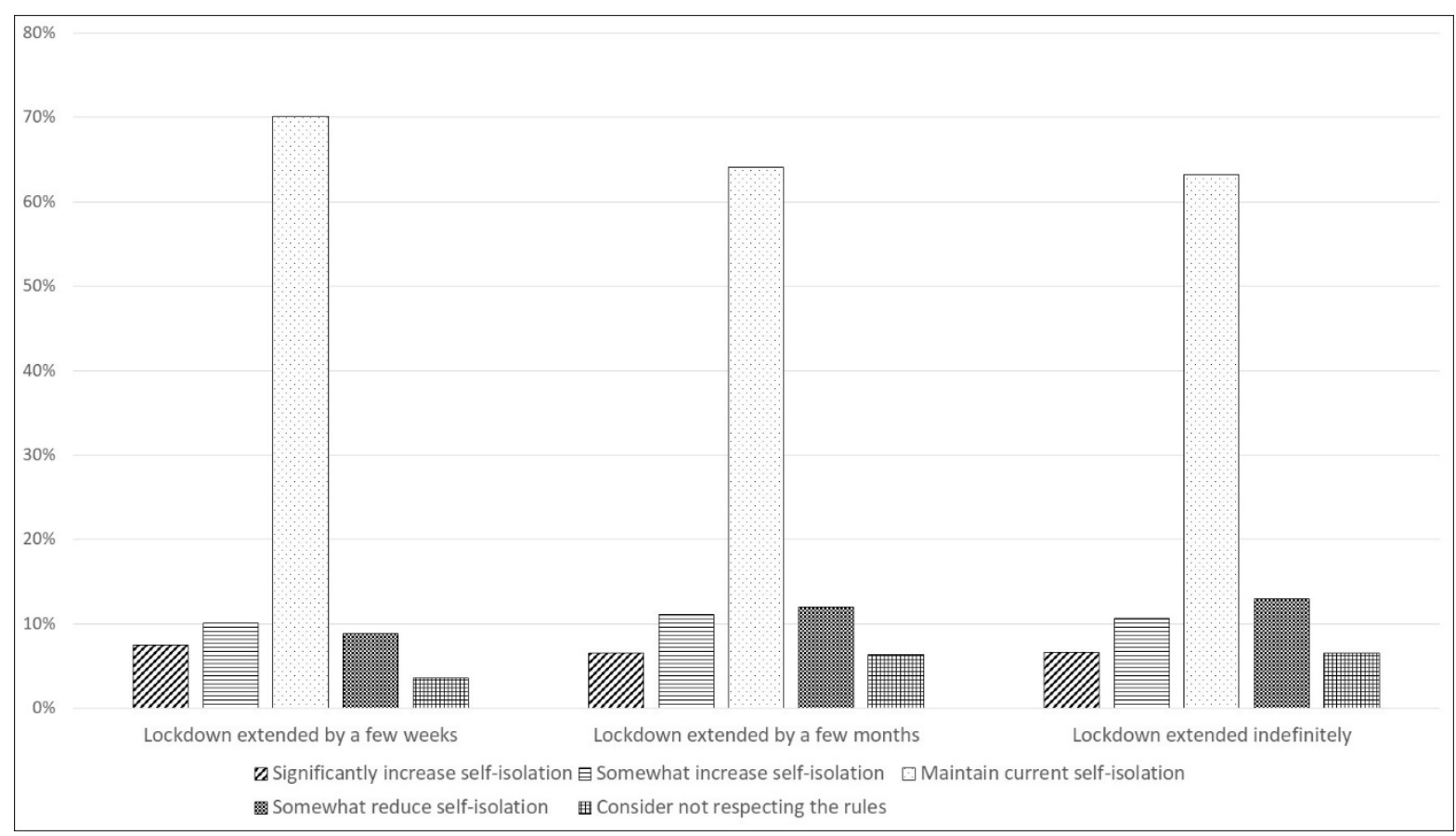

Notes: The chart reports the share of respondents who indicated their intention to maintain, increase or reduce their compliance with self-solation provisions, separately by the different extension scenarios. We used sampling weights to compute these statistics (SWG provided the weights). 
FIGURE C10: Self-isolation intentions, by (mis)match between expectations and extension scenarios,

by wave

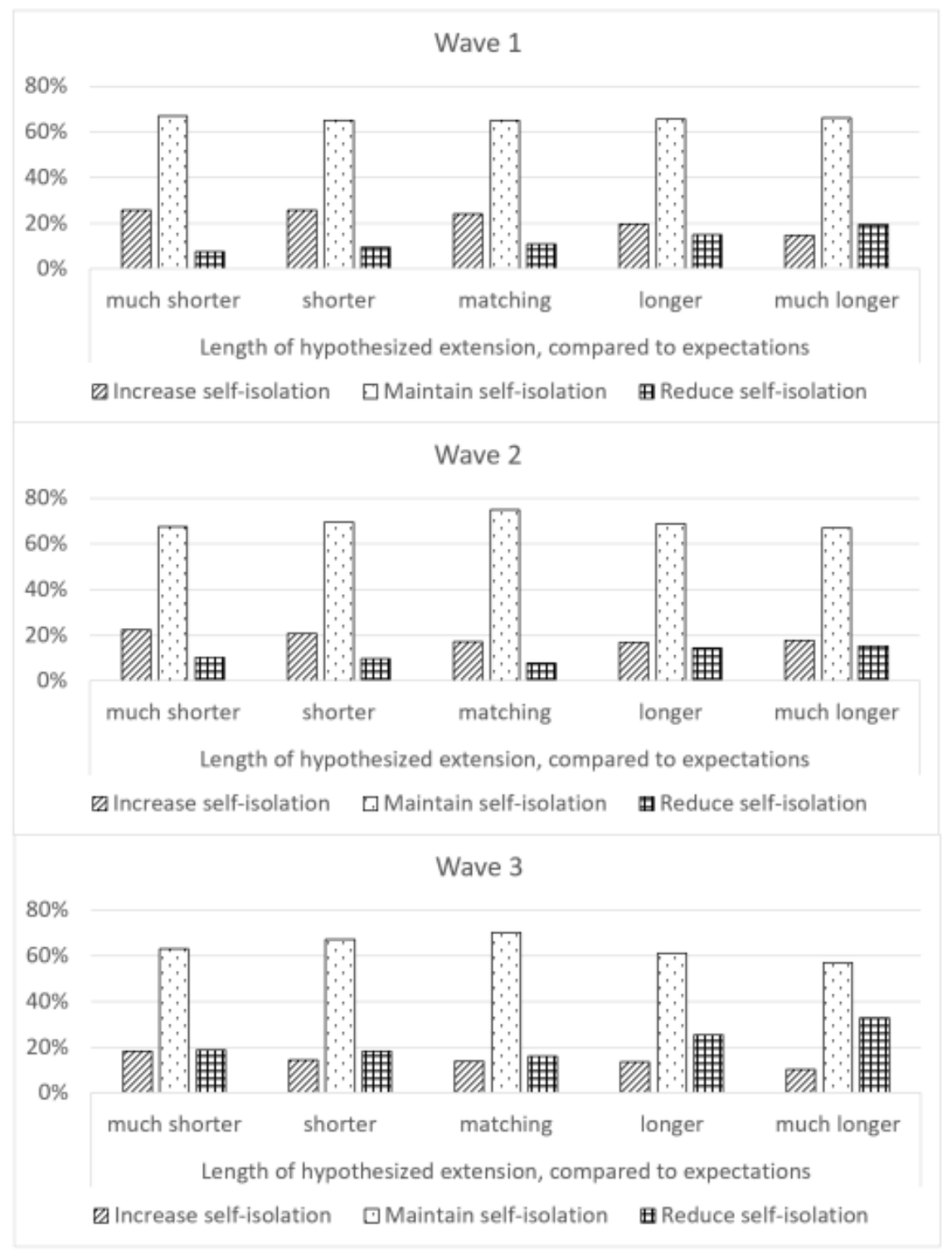

Notes: "Increase self-isolation" corresponds to the intention to either "increase substantially" or "increase somewhat" self-isolation; "Reduce self-isolation" includes the options "reduce somewhat" or "consider not complying with restrictions"; "Maintain self-isolation" indicates intention to "continue with current self-isolation behavior". We used frequency weights to compute these statistics (SWG provided the weights). The graph also reports confidence intervals and the value of the design-based Fstatistics from a test of differences in distributions. 